1995

\title{
Attorney and Judicial Perceptions of the Credibility of Expert Witnesses in Child Custody Cases
}

Michael T. Foot

Follow this and additional works at: https://scholarscompass.vcu.edu/etd

Part of the Psychology Commons

(C) The Author

\section{Downloaded from}

https://scholarscompass.vcu.edu/etd/4568

This Thesis is brought to you for free and open access by the Graduate School at VCU Scholars Compass. It has been accepted for inclusion in Theses and Dissertations by an authorized administrator of VCU Scholars Compass.

For more information, please contact libcompass@vcu.edu. 


\section{College of Humanities and Sciences \\ Virginia Commonwealth University}

This is to certify that the thesis prepared by Michael T. Foot entitled "Attorney and Judicial Perceptions of the Credibility of Expert Witnesses in Child Custody Cases" has been approved by his committee as satisfactory completion of the thesis requirement for the degree of Master of Science.

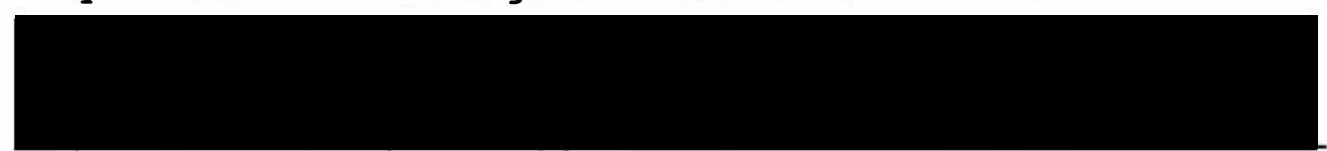

Arnold L. Stolberg, Ph.p.y Director of Thesis

Mjtah L. McCreary, Ph.D., Committee Member

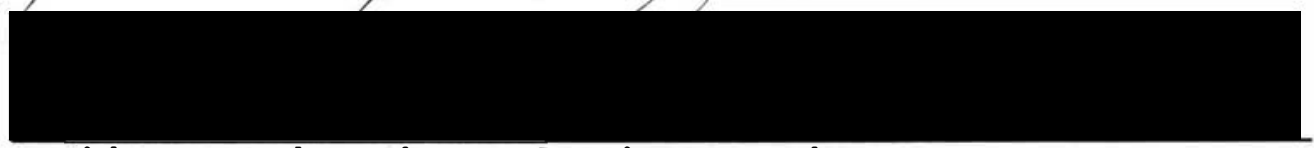

David D. Franks, Ph.D., Committee Member

Robert E. Shepherd, LVL.B., Committee Member

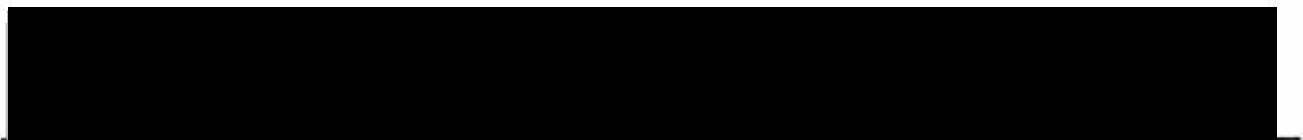

Stanley R./Strong, Ph.D., Director of Graduate Studies
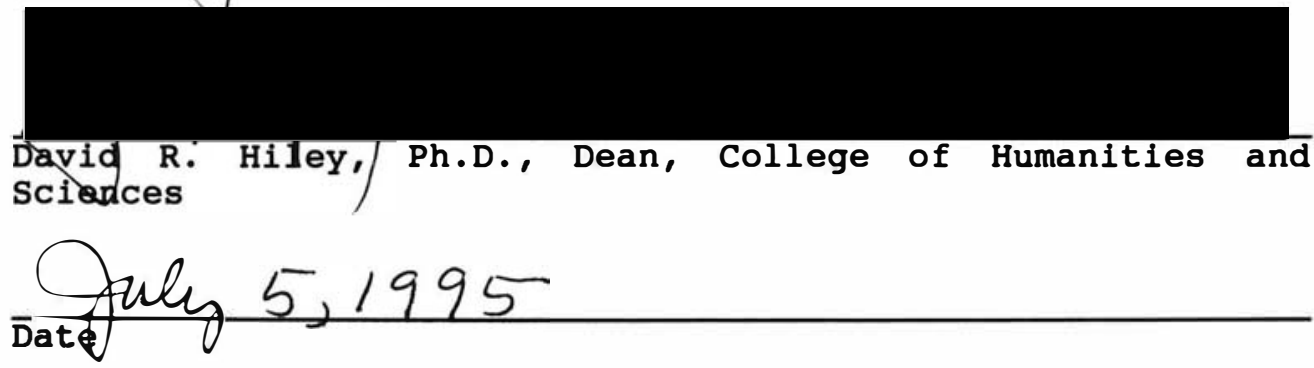
Attorney And Judicial Perceptions of The Credibility of Expert Witnesses In Child Custody Cases

A thesis submitted in partial fulfillment of the requirements for the degree of Master of Science at Virginia Commonwealth University.

\author{
By \\ Michael T. Foot \\ B.A., University of Virginia, 1989 \\ Director: Arnold L. Stolberg, Ph.D. \\ Professor of Psychology
}

Virginia Commonwealth University

Richmond, Virginia

August, 1995 
Acknowledgements

I would like to thank Arnold Stolberg for his help during this project. Without his unflagging support, I would have been unable to complete this project. I would also like to thank my committee members David Franks, Micah McCreary, and Robert Shepherd for their continued encouragement and helpful comments. Lastly, I would like to thank my wife Kristin Blais for her valuable editorial reviews and reminders of the truly important priorities in life. 
Table of Contents

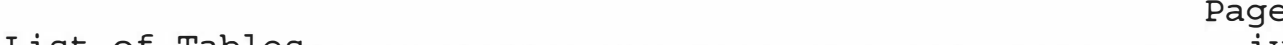

List of Tables......................... iv

List of figures...................... v

Abstract.............................. vi

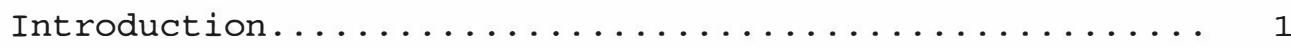

History of Custodial Presumption................ 3

Psychologists in the Courtroom................ 8

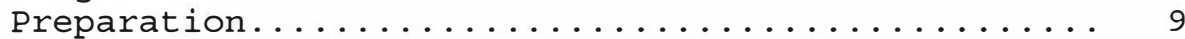

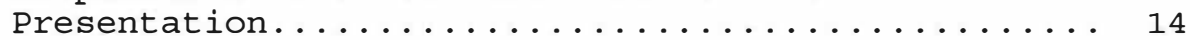

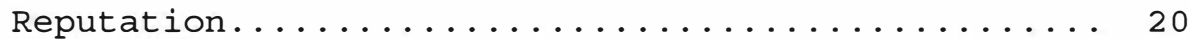

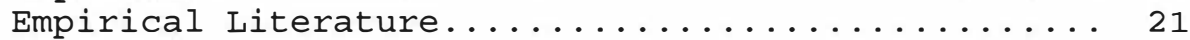

Judicial Views....................... 24

Previously Established Methodologies............. 26

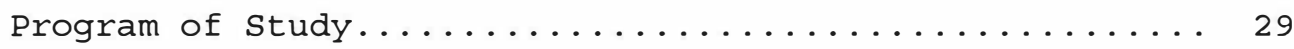

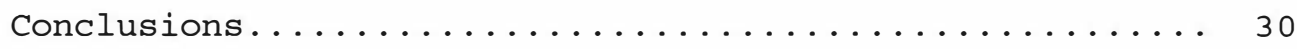

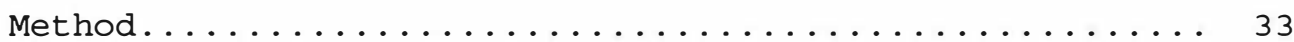

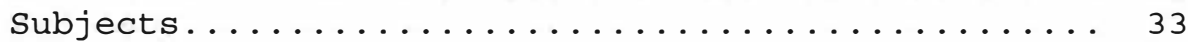

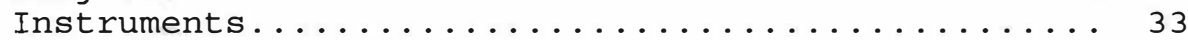

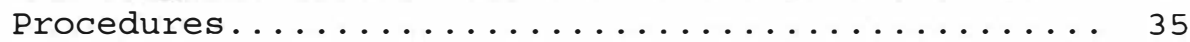

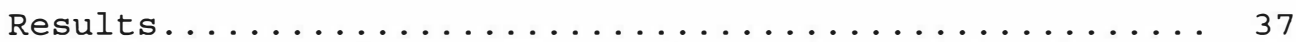

Subjective Expert Witness Rating Form (SEWRF) ..... 40

Traditional Court and Family Assessment Form

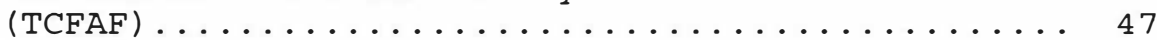

Knowledge Assessment Form (KAF) ............... 54

Subjective Expert Witness Rating Form, Item

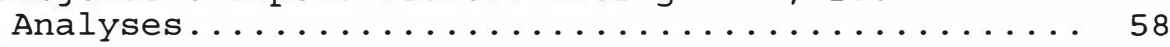

Relationships Among Scales................. 60

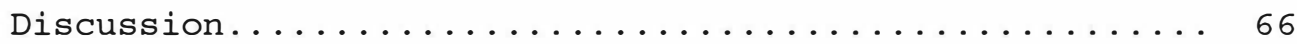

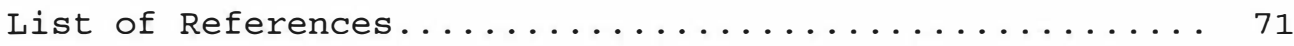

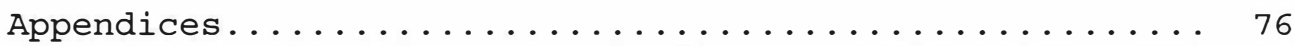

A. Demographic and Attitudinal Questionnaire (DAQ) 76

B. Subjective Expert Witness Rating Form (SEWRF).. 79

C. Traditional Court and Family Assessment Form

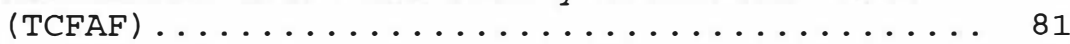

D. Knowledge Assessment Form.............. 83 
List of Tables

Table

Page

1. Correlations Between the Scales of the SEWRF and the

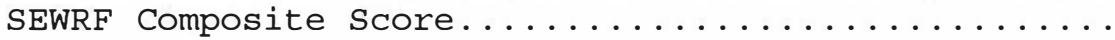

2. Items and Reliability Estimates for the scales of the

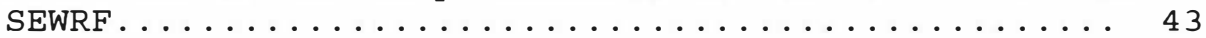

3. Principal Components Analyses of the SEWRF: Rotated

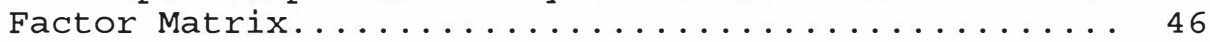

4. Scale/Composite Correlations for the Traditional Court and Family Assessment Form (TCFAF) ............ 48

5. Principal Components Analysis of the TCFAF: Rotated

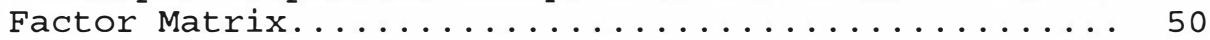

6. Items and Reliability Estimates for the Scales of the

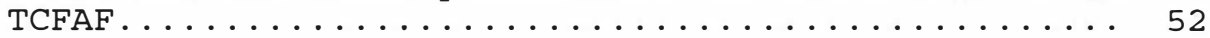

7. Items and Item Analyses of the Knowledge Assessment

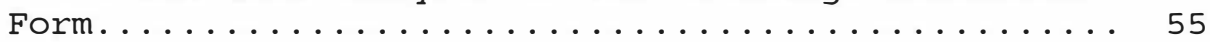

8. Largest Item/Total Correlations for the SEWRF..... 59

9. Correlations Between the Scales on the SEWRF, TCFAF,

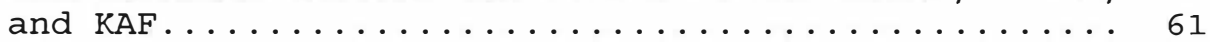

10. Unique Scale Contributions to the General and Specific Perceptions of Expert Witnesses (Semipartial

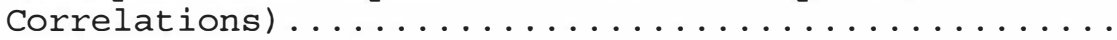

11. Regression Analyses of Demographic Variables on the SEWRF Composite and a General Measure of Perceived Expert Witness Helpfulness (Semipartial Correlations) 65 
List of Fiqures.

Figure

Page

1. Program of study...................... 30 
Abstract

ATTORNEY AND JUDICIAL PERCEPTIONS OF THE CREDIBILITY OF EXPERT WITNESSES IN CHILD CUSTODY CASES

Michael T. Foot

A thesis submitted in partial fulfillment of the requirements for the degree of Master of Science at Virginia Commonwealth University.

Virginia Commonwealth University, 1995

Major Director: Arnold L. Stolberg, Ph.D. Department of Psychology

Attorney and judicial attitudes towards expert witnesses in child custody cases were investigated by a cross-sectional research design. Subjects consisted of a sample of 381 of all attorneys and judges in the Commonwealth of Virginia who wished to be certified as guardians ad litem. Subjects were asked to fill out a six page questionnaire immediately prior to a daylong certification training session. The sample was primarily white $(85.2 \%)$ and male $(57.7 \%)$. Information was gathered on the subjects' demographic characteristics, experience with and attitudes toward expert witnesses in custody cases, opinions on traditional court and family structures, and knowledge of developmental and parenting psychology. Factor analyses and examination of the reliability of the instruments allows the development of more reliable and valid measures for model testing. Results generally 
confirmed Banks \& Poythress' (1982) tripartite theory of credibility as being composed of perceived expertise, trustworthiness, and dynamism. Characteristics of attorneys and judges were also shown to be an important contributor to their perceptions of expert witnesses in child custody cases. Specifically, those courtroom professionals who had greater training, knowledge, and experience relevant to custody cases tended to view specific expert witnesses more positively. Those attorneys and judges with more traditional court attitudes rated expert witnesses in general as less helpful. However, these traditional attitudes did not cause them to devalue expert witness testimony in specific cases. This study is part of a larger program of study which will attempt to determine the extent to which the quality of expert witness testimony effects perceptions of their credibility, and how perceptions of expert witness credibility relate to judicial decisionmaking in child custody cases. 


\section{Introduction}

Determining custody in parental divorce involving minor children is an ever-growing problem for the legal system in America. It has been estimated that the 90's will see $33 \%$ of all children in the United States experiencing the divorce of their parents before they reach the age of 18 (Norton \& Glick, 1979). Though 85-90\% of the custody decisions in these cases are decided outside of the courtroom (Felner, Terre, Farber, Primavera, \& Bishop, 1985), the approximately $10 \%$ of the cases that are adjudicated are frequently the most difficult cases. Extreme conflict between the parents, allegations of parental mental illness or child abuse, and difficult choices between equally competent parents often characterize these cases (Ash \& Guyer, 1984). To further complicate matters, the guidelines by which the court decides the adjudicated cases are poorly enunciated (Davis \& Stolberg, 19988; Felner, Terre, Farber et al., 1985; Wyer, Gaylord, \& Grove, 1987). The mental health professional, a source who may provide some guidance in matters of child and family adjustment, is relegated to a vague role in the courtroom process .

Divorce can have far reaching consequences on the 
future psychological functioning of the children involved (Davis \& Stolberg, 1988; Felner, Terre, Farber et al., 1985). Reorganization of the family, if done properly, affords an opportunity to prevent the development of maladaptive behavior in children that is often associated with divorce (Felner, Terre, Farber et al., 1985). The process and outcome of the child custody arrangements is an integral part of this reorganization (Felner et al., 1980). The social, emotional, and cognitive development of children at two years following divorce has been shown to be much more strongly related to the characteristics of the custodial parent, further highlighting the importance of child custody decisions (Hetherington, Cox, \& Cox, 1976). The question of how the courts may decide the optimal custodial arrangement for the child is, at best, a difficult choice which may be compounded by a high case load and the fact that judges often lack even the most basic information about the child or parent's life (Mnookin, 1975). 
History of Custodial Presumption

Historically, questions of custody were rarely debated since children had no rights and were considered the property of their fathers (Foster, 1983; Oster, 1965). By the twentieth century, nominal equality was established, though the presumption of custody now fell to the mother, especially if the child was very young (Foster, 1983; Oster, 1965). More recently, the acknowledge standard has become the "best interest of the child" (Mnookin, 1975). Yet, professionals on all sides of the issue are uncertain as to what exactly "best interest" means. There has been considerable debate as to whether the "best interest" means the current or future happiness of the child, the spiritual or religious training given to the child, the projected economic productivity of the child, or the stability or intellectual stimulation available to the child (Mnookin, 1975). Whatever the definition of "best interest", the information necessary to make a sound and responsible child custody determination is not readily apparent. Most states lack any specific criteria for determining best interest of the child, and those that do often fail to specify weights or priorities among the various criteria (Wyer et al., 1987). "Unsubstantiated assumptions and presumptions, inconsistent case law, vague and indefinite statutes and criteria and personal biases" (Marafiote, 1985, p. 4) are 
often used by judges as bases for their custody decisions. The importance of custody decisions and the vagaries of custody guidelines for judges has led one justice to state that "a judge agonizes more about reaching the right result in a contested custody issue than about any other type of decision he renders" (Botein in Oster, 1965, p. 23).

It is here that the psychologist or mental health worker may be able to assist the legal arena in its decision-making. Mental health experts are in a position to supply the court with additional information about the family members involved in the custody dispute and research findings relating to post-divorce adjustment. Though criticisms of mental health professionals as expert witnesses are not uncommon (Faust \& Ziskin, 1988; Okpaku, 1976), the use of psychological testimony is becoming increasingly accepted (McCloskey, Egeth, \& McKenna, 1986). The skills that psychologists may bring to the legal arena are those of "interviewer; observer; structurer and organizer of observed interactions (e.g., family interactions); administrant and interpreter of specialized assessment techniques; and conceptual organizer and interpreter of disparate and diverse supplementary data sources (e.g., school, medical, employment, social service, or court records)" (Weithorn \& Grisso, 1987, p. 170-71). While psychologists in the courtroom have been 
criticized for the excessive generality of their beliefs (Litwack, Gerber, \& Fenster, 1979-80), a lack of empirical data about how adult behavior affects children (Litwack et al., 1979-80), and insufficient research into the effects of various types of custodial arrangements (Weithorn \& Grisso, 1987), the more expansive view holds that psychologists are in a position to increase the amount of information available to the court. Indeed, it has been argued that: the issue is not whether psychologists or psychiatrists can predict the outcome of alternative custody arrangements with anything approaching absolute accuracy, but whether psychological testimony can provide the court with information, not otherwise readily available to the court, which will increase, however slightly, the accuracy of the prediction the court must make (Litwack et al., 1979-80, p. 283).

In order to be acceptable in court, the 1975 Federal Rules of Evidence hold that expert testimony must "assist the trier of fact to understand the evidence or to determine a fact in issue" (Rule 702). Perhaps the most succinct test of the worth of psychological testimony was written by U.S. Circuit Court Judge David L. Bazelon and states that testimony should be allowed that "will be likely to aid the trier in the search for the truth" (Jenkins v. U.S. (1962) in Horowitz \& Willging, 1984). 
Psychologists in the courtroom are, therefore, in a position to impress upon the court the necessity of safeguarding the child's psychological well-being, a concern that decision makers have been slow to take into account (Goldstein, Freud, \& Solnit, 1973). In addition to their observational training, psychologists may also inform the courts of research related to custody decisions (Weithorn \& Grisso, 1987). For example, judges and lawyers admit to having significant difficulty weighing and interpreting the wishes of the child (Felner, Terre, Goldfarb, Farber, Primavera, Bishop, \& Aber, 1985). Psychologists may inform the courts of their knowledge of child development as an aid to deciding how to best interpret the wishes of different children of different ages. Psychologists may also help to clarify the child's feelings and make these feelings more coherent to the court.

Attempts have been made to formalize the factors necessary to consider in child custody cases. Though they have not been formally adopted by the courts, the model Uniform Marriage and Divorce Act of 1973 was adopted by the American Bar Association in 1974 and specifies for the court to consider all relevant factors including the following:

1) the wishes of the child's parent or parents as to his custody;

2) the wishes of the child as to his custodian; 
3) the interaction and interrelationship of the child with his parent or parents, his siblings, and any other person who may significantly affect the child's best interest;

4) the child's adjustment to his home, school, and community; and

5) the mental and physical health of all individuals involved. The court shall not consider conduct of a proposed custodian that does not affect this relationship to the child.

The mental health experts, by virtue of their training and time spent evaluating the parents, children, and other sources may well have more information about the family than the judge (Litwack et al., 1979-80; Mnookin, 1975), and will be able to significantly add to the information available to the judge regarding the five issues above.

Another function of psychological evaluations for the court may be, ironically, the avoidance of litigation. Occasionally, judges order evaluations to delay trials and allow the parents to settle their differences outside the courtroom (Bradbrook, 1971). There is some empirical support for the delay tactic. For instance, in Ash \& Guyer's (1984) divorce study, sixty-two percent of parents accepted the recommendations of the mental health evaluator, and thus avoided adjudication. 
Psychologists in the Courtroom

For cases that are adjudicated, mental health professionals are often called to testify in court. As previously stated the mental health professional is in a good position to increase the knowledge available to the court, and thus it is important that this testimony be effective and worthwhile. In order to be effective, the mental health professional must appear credible to the judge (Skafte, 1985). If the expert's testimony is not credible, the court's knowledge of the psychosocial issues relating to the case may not be increased. Credibility is an important link between the information of the expert witness and the court's decision-making process, therefore, this study will elucidate the processes that influence expert witness' credibility in the courtroom.

Far too often, mental health workers are not be properly trained to testify in court. One psychologist familiar with testifying in the courtroom warns that "expert witness roles call for attitudes, outlooks, and behaviors that are different from most mental health professional roles" (Brodsky, 1991, p. 133). Such a drastic shift of function may confuse the mental health professional not familiar with the courtroom, thus reducing his or her effectiveness in the legal arena. The literature on credibility and effectiveness of the mental health 
professional in the courtroom addresses how the expert may be most effective, and may be thought of as being composed of several layers: preparation, presentation, and reputation.

Preparation

One aspect of credibility in the courtroom is thought to be related to the psychological "wholeness" of the mental health professional's information (Watson, 1978). An expert witness may only impart psychologically whole information to the court if he or she has properly prepared. Preparation may be thought of as including the following: a clear delineation of the expert's role, a thorough evaluation, a well-written report, and familiarity with court layout and procedure.

Even before the assessment begins, the evaluator must be thinking of ways to maximize credibility. Once an evaluation is assigned to a particular mental health worker, the first thing the evaluator must do is to clearly separate the roles of evaluator and therapist (Skafte, 1985). A psychologist used to the therapy role will have a natural urge to affiliate with the "client" (Brodsky, 1991). However, as judges have been shown to be most positively inclined toward experts who attempt to be objective (Blau, 1984), the expert must be aware of, and attempt to minimize the "pull to affiliate" (Brodsky, 1991). A more effective 
way of reducing affiliation to one parent is attempting to work with both parties, which ensures that the expert does not have any built-in biases toward one parent or the other. Such a bipartisan focus eliminates the "battle of the experts" and increase credibility (Watson, 1978). Working with both parents also helps to ensure that the "best interests" of the child are not lost in the battle between the parents (Derdeyn, 1975). If, however, it is not possible to work for both parents, the evaluator should request a retainer before the trial to reduce the appearance that the expert's fee is based on the testimony given. This will decrease perceptions of bias, and increase credibility (Schutz, Dixon, Lindenberger, \& Ruther, 1989).

The next level of preparation related to psychological "wholeness" involves the evaluation. Few commonly accepted guidelines exist as to what constitutes a thorough evaluation. However, three elements thought to be necessary to assess in a custody evaluation are the continuity and duration of the relationship between the child and parent, the feeling of the parents toward the child, and the feeling of the child toward both parents (Mnookin, 1975). Interviews with the children, both parents, and any other caretakers, an assessment of the child or parent's functioning outside of the psychologist's office (home, school, work, community), and a review of relevant 
educational and medical records are all necessary to ensure that the psychologists sees the family members in a broad range of settings (Weithorn \& Grisso, 1987). The use of projective tests has been discouraged as difficult to defend in the courtroom (Marafiote, 1985). In addition to a complete evaluation, the mental health evaluator must keep relevant, thorough, and accurate records (Horsley \& Carlova, 1983), keeping in mind that such records may become evidence for the court.

The report of the evaluation to the court must also be carefully and concisely written. The report should focus on the child's needs and desires rather than the parent's (Foster, 1983). To be most effective, the audience for the report should first be the judge, and then attorneys and parents (Skafte, 1985). The language of the report should be "precise, austere, and free from jargon, legal terms, vague abstractions, psychological terms that have been corrupted by popular usage and terms that are pejorative in reference to any party" (Schutz et al., 1989, p. 94). One psychologist familiar with child custody cases argues that judges can better use positive information than negative. For example, the more helpful statement would be that Home $A$ is more suitable to the child for the following reasons, rather than Home B will be less suitable (Skafte, 1985). It is also extremely important that every report substantiate 
and support objectively the findings of the evaluator, and clarify exactly how the evaluator arrived at his or her conclusions (Blau, 1984; Skafte, 1985; Weithorn \& Grisso, 1987). The conclusions of the report need not, and should not, rely on "personality theory" or "concepts of mental disorder", relying instead on the common sense notion that people will continue to act as they have acted in the past (Litwack et al., 1979-80). Opinions about parties not directly assessed should never be offered (Weithorn \& Grisso, 1987), and when repeating statements made by family members about other members, it is always necessary to acknowledge such statements as hearsay (Marafiote, 1985). In general, a report that is organized, objective, and free from extraneous information will increase the likelihood that the judge will receive the information presented (Skafte, 1985).

The mental health expert also needs to prepare adequately for testifying in court. To maximize effectiveness, the expert must be familiar with the laws, statutes, regulations, and established criteria relating to the case being tried (here, child custody decisions) (Anchor \& Sieveking, 1981; Anchor, 1984). The expert should also be familiar with the relevant scientific literature (Blau, 1984; Brodsky, 1991; Horsley \& Carlova, 1983), and be prepared to discuss the literature that both supports and 
opposes factors used by the evaluator (Horsley \& Carlova, 1983). Additionally, psychologists should be familiar with the reliability and validity of any standardized assessment techniques they use (Weithorn \& Grisso, 1987). One psychologist familiar with testifying in court recommends that the expert be prepared to discuss the following in regard to the use of standardized assessment techniques: 1) the meaning of terms used, 2) the accuracy and appropriateness of assessment techniques, 3) the reliability of assessment techniques, 4) the validity of assessment techniques, 5) the accuracy of the scoring of assessment techniques, 6) the certainty of the conclusions reached, 7) alternate (unselected) evaluation techniques, 8) alternate interpretations of the tests, and 9) the recommendations based partly on the test results (Anchor, 1984).

Many authors stress the necessity of meeting with the attorney(s) before testifying in order to devise a strategy to most effectively relate the expert's information to the court (Anchor \& Sieveking, 1981; Anchor, 1984; Bank \& Poythress, 1982; Blau, 1984; Brodsky, 1991; Foster, 1983; Horsley \& Carlova, 1983). It is helpful to prepare a current curriculum vitae to present to the attorneys and the court as evidence of expertise in the child custody area (Anchor, 1984). Prior to testifying, the expert should review the main points of the case (Foster, 1983; Marafiote, 
1985; Hilton, 1968) so that he or she is able to testify without referring to notes (Marafiote, 1985). This review should also include the deposition transcript (Blau, 1984). While it is good to be prepared, it is important to remember that over-rehearsal or memorization of testimony will make the testimony look scripted, and hence, less credible (Horsley \& Carlova, 1983; Watson, 1978).

Finally, many mental health professionals find that anxiety about their appearance in court may interfere with their testimony (Brodsky, 1991). To reduce this, some writers recommend that experts become familiar with the courtroom before testifying (Blau, 1984; Brodsky, 1991; Horsley \& Carlova, 1983). This can include visiting the court on an off day, or watching another trial to get acquainted with the layout and protocol of the courtroom (Blau, 1984; Brodsky, 1991). Also, arriving one-half hour early for testimony will avoid anxiety due to traffic delays, parking difficulties, etc (Horsley \& Carlova, 1983). Familiarity with courtroom procedures and layout may increase the expert's sense of control, making the expert's testimony surer and more credible.

Presentation

The importance of making a good first impression is well established. Expert witnesses too need to make a good impression on the judge to be most effective. One of the 
first things the judge will know about the witness is how they are dressed. Those familiar with the courtroom point out the necessity of professional dress with an absence of distracting accessories (Blau, 1984; Brodsky, 1991; Horsley \& Carlova, 1983; Nichols, 1982). Actions of the expert unrelated to the testimony are also thought to influence the impression the witness makes upon the judge. When the expert is being sworn in, he or she should take the oath "clearly and formally" (Horsley \& Carlova, 1983, p.59). After being sworn in and seated, the expert should turn and acknowledge the judge with a simple "good morning your honor" (Blau, 1984). Good posture, with feet placed flat on the floor, is thought to increase perception of control in the witness, and translate into a more effective bearing (Brodsky, 1991; Horsley \& Carlova, 1983). When answering questions, initiating eye contact and addressing the judge is hypothesized to increase attention of the judge and allow the expert to better gauge if the testimony is being fully understood (Anchor \& Sieveking, 1981; Brodsky, 1991; Schutz et al., 1989). More generally, remembering that personal characteristics and relational skills are thought to be very important in other's perception of testimony, may help the expert maximize effectiveness and credibility (Linz, Penrod, \& McDonald, 1986; Pipkin, 1989) .

To be most effective, testimony should be presented in 
a manner that is "simple, clear, organized, and logical" (Linz et al., 1986, p. 282). Using the evaluation report as a thematic framework with which to structure testimony is thought to best allow judges and attorneys to organize and process the information presented (Linz et al., 1986). As in the report, critical factors in testimony are believed to be the logic and methods that the psychologist uses to arrive at his or her findings, conclusions, and recommendations (Anchor \& Sieveking, 1981; Bazelon, 1975; Hilton, 1968; Litwack et al., 1979-80). Witnesses must articulate reasons for opinions (Anchor \& Sieveking, 1981; Litwack et al., 1979-80), and back up facts and opinions with documentation (Foster, 1983,19d). Observations should be straightforward reports of behavior, and not diagnoses (Weithorn \& Grisso, 1987). Facts, observations, and opinions should be clearly and unambiguously separated during testimony (Weithorn \& Grisso, 1987). One pitfall to always avoid during testimony is that of using psychological jargon, labels, or technical terms instead of describing behavioral observations (Anchor \& Sieveking, 1981; Bazelon, 1975; Skafte, 1985). If the use of technical terminology is unavoidable, the expert should define the term and use an example to clarify its meaning (Anchor, 1984). It has been argued that psychiatric diagnoses should be inadmissible in custody proceedings (Litwack et al., 1979-80). 
The objectivity of the expert witness may be one of the most important factors in the judge's perception of the expert's credibility (Blau, 1984). Indeed, some judges have been known to get angry at expert witnesses who act as an advocate for one side (Saxe, 1975). Unbiased sources have been shown to be more credible than biased sources with similar levels of expertise (Bank \& Poythress, 1982; Pipkin, 1989). Given this, avoiding the appearance of bias becomes extremely important when attempting to maximize credibility. Taking special care to present the evidence fairly, objectively, and accurately is surmised to be a necessary component of the expert's credibility (Hilton, 1968; Horsley \& Carlova, 1983; Nichols, 1982). A common method thought to reduce the appearance of bias is to admit to the qualifications of the testimony freely during the direct examination (Anchor, 1984; Bank \& Poythress, 1982; Foster, 1983; Hilton, 1968; Schutz et al., 1989; Watson, 1978). Another technique believed to reduce the perception of bias is to show flexibility in conclusions and predictions (Foster, 1983), and avoid overstatements or absolutes (Schutz et al., 1989). Additionally, experts who openly admit to being paid for their time and expertise (not testimony) (Horsley \& Carlova, 1983; MCClosky et al., 1986; Schutz et al., 1989), and state how they overcame possible bias (Brodsky, 1991) may be more effective. 
Another way hypothesized to increase trust in the expert is for the expert to appear human and not feign omniscience (Anchor, 1984; Brodsky, 1991). A willingness to admit to the limits of expertise may be positively related to effectiveness of testimony (Brodsky, 1991; Horsley \& Carlova, 1983; Schutz et al., 1989; Woocher, 1986). Likewise, an expert should never attempt to answer a question he or she does not fully understand (Nichols, 1982; Schutz et al., 1989). Moreover, if a question cannot be answered with a "yes" or "no", the expert witness should ask the judge for permission to elaborate (Marafiote, 1985; Nichols, 1982; Schutz et al., 1989).

The demeanor of an expert witness may also play a role in the credibility of that witness. One essential element of this demeanor is emotionality. The witness should never let emotion interfere with his or her testimony (Anchor \& Sieveking, 1981; Anchor, 1984; Blau, 1984; Foster, 1983; Horsley \& Carlova, 1983). In fact, it has been posited that "the more volatility, the more sermonizing, the more harangues and histrionics, the less credibility will the evaluator have" (Marafiote, 1985, p. 268). Care must be taken to have the same polite, non-defensive demeanor for cross-examination as during direct-examination (Horsley \& Carlova, 1983; Nichols, 1982). A relaxed and sensible dignity is thought to be most likely to be effective in the 
courtroom (Blau, 1984; Horsley \& Carlova, 1983). On the contrary, testimony that is perceived as overdramatic or phony is thought to be less persuasive (Brodsky, 1991). Humor is seldom effective or welcome in the courtroom (Marafiote, 1985).

The type and quality of speech that witnesses use is also hypothesized to be related to the effectiveness of an expert's testimony. Effective witnesses speak clearly (Horsley \& Carlova, 1983) and slowly (Brodsky, 1991), varying the loudness of their speech to maintain listener interest (Brodsky, 1991). They also vary the format of their responses to avoid repetitive sentence structures that may bore the listeners, and stress certain syllables to make their speech more listenable (Brodsky, 1991). The witness who makes clear the conviction of his or her position is also thought to be more effective (Brodsky, 1991; Marafiote, 1985). Effective witness testimony is also believed to include proper pacing (not responding too quickly or slowly to questions from attorneys) (Brodsky, 1991; Horsley \& Carlova, 1983). Additionally, it is recommended that the expert lean forward occasionally to engage the judge (Brodsky, 1991). In sum, good speech for expert testimony calls for the expert to put on a "good show" which will hold the listeners' interest without coming across as overacting (Hilton, 1968). 
Finally, to ensure future testimony is as credible as possible, it is recommended that the expert ask for a copy of the court transcript. The transcript can be used to note discrepancies or inadequacies in testimony, and may be used as an aid for better testimony in the future (Blau, 1984). It may also be helpful to have a colleague critique the testimony of the expert. (Linz et al., 1986). Ironically, those experts with the most courtroom experience may be the one who would benefit maximally from this. A study of courtroom exposure and effectiveness in attorneys showed that greater trial exposure consistently related to overestimation of favorable self-impression and underestimation of unfavorable self-impression (Linz et al., 1986).

Reputation

Though often overlooked in the literature, the credibility of an expert witness may be affected by the previous behavior of the witness. The reputation of an evaluator as a "hired gun" may precede the witness into the courtroom, and negatively impact his or her credibility with the judge (Horsley \& Carlova, 1983; Skafte, 1985). Even the behavior of others in the field may affect the general perception of the credibility of mental health professionals, as was shown by the public's negative perception of psychiatrists during John Hinckley's trial 
after he attempted to assassinate Ronald Reagan (Sharf, 1986).

The qualifications of the expert will also affect his or her credibility. Before testifying as an expert witness, a mental health professional should have demonstrated advanced training and experience in the field (generally a doctorate), published research in the area, and studied the work of other relevant authors (Anchor \& Sieveking, 1981; Horsley \& Carlova, 1983; Woocher, 1986). Professional recognition, board certification, and membership in meaningful professional associations is also thought to positively contribute to the credibility of the expert (Horsley \& Carlova, 1983).

Empirical literature

The bulk of the previous section, while helpful in hypothesizing the contributing factors to the credibility and effectiveness of expert witnesses, is composed mostly of practical (non-empirical) information by those familiar with mental health professionals in the courtroom. There is also an empirical body of evidence which may be applied either directly or indirectly to the credibility of expert witnesses.

Credibility has been described as being composed of three components: expertise (training, experience, and other indices of professional competence), trustworthiness 
(apparent honesty and objectivity of witness), and dynamism (presentational style) (Bank \& Poythress, 1982). Several studies have been done attempting to determine the relative importance of the various factors.

The relative importance of trustworthiness and expertise was tested by presenting college students from four different countries with a written argument accredited to writers of varying trustworthiness and expertise. The researchers found that the argument credited to the trustworthy sources were consistently rated more favorably than the untrustworthy ones, regardless of expertise (MCGinnies \& Ward, 1980).

In contrast to this finding, another study attempting to distinguish between the effects of expertise and bias, found that "the weight of a source's communication depends mostly on the source's expertise, but diminishes if the source is biased" (Birnbaum \& Stegner, 1979, p. 72).

Dynamic testimony was the focus of a study in which an actor was presented as an expert, and spoke dynamically to a group of highly trained professional educators (Naftulin, Ware, \& Donnelly, 1973). However, he had been instructed to use "excessive double talk, neologisms, non sequiturs, and contradictory statements" (Naftulin et al., 1973, p. 631). After the lecture, the unsuspecting educators gave "Dr. Fox" more favorable than unfavorable reviews. Even for the 
educators, assumptions of credibility outweighed any objective examination of the lecture.

Further highlighting the importance of presentation in determining credibility, direct testimony was found to be better retained and more persuasive than the same testimony read by an attorney (Jacoubovitch, Bermant, Crockett, McKinley, \& Sanstad, 1977). Jurors reported more reliance upon, and higher confidence in specific testimony that spelled out the factors highly relevant to the case being tried than they did to general testimony which outlined the basic processes relevant to the type of situation explained (Fox \& Walters, 1986).

"Powerful" speech, that uses fewer hedges ("I think","it seems like"), hesitation forms ("um", "well"), polite forms ("sir", "please"), less question intonation (declarative statement with rising intonation so as to convey uncertainty), and fewer overused intensifiers ("very", "surely") was found to be more convincing than "powerless" speech (Conley, O'Barr, \& Lind, 1978).

Additionally, witnesses who used long narrative answers to questions from lawyers were rated as more competent when compared to witnesses using a more fragmented delivery (Conley et al., 1978).

Taken together, it may be hypothesized that, testimony that is direct, narrative, "powerful", dynamic, unbiased, 
trustworthy and expert will be rated more favorably than testimony that is not all of the above.

Judicial views.

Another definition of credibility is that it is "a set of perceptions about sources held by receivers" (Bettinhaus, 1973, p. 134). Because judges are the primary "receivers" of expert testimony, it is important to consider their view of mental health professionals in the courtroom. Judges asked to rate twenty items pertaining to their decisionmaking in child custody cases rated "professional advice" as the twelfth most important item on the list (Lowery, 1981), suggesting that the findings of expert witnesses were given a moderate amount of consideration. This finding was supported by another study on judicial attitudes towards expert witnesses (Sorensen \& Goldman, 1989).

However, when judges' custody decisions were compared to the recommendations of mental health evaluators in ninety-two custody cases, it was found that the court agreed with the custody evaluator's report $92 \%$ of the time (Ash \& Guyer, 1984). This should not be surprising given that judges and mental health professionals generally agree on what is important in child custody cases (Settle \& Lowery, 1982). It may be that judges do not like to presume reliance upon expert witnesses, but credible evaluators can present information to the judge that he or she will accept 
as reasonable.

Judicial reactions to expert testimony have also been shown to be affected by the judges' training, background, and experience (Foster, 1983). For example, liberal judges in a study of custody decisions tended to place more weight on psychological evaluations and less on the social deviance of the parents (Sorensen \& Goldman, 1989). 
Previously Established Methodologies

Few, if any, studies have attempted to assess attorney and judicial perceptions of expert witness credibility in child custody cases -- making it more difficult to find methodologies that have been used successfully. However, there are several types of studies that are similar enough to the proposed study to inform its design. These studies are: 1) studies which assess judicial attitudes about related (or unrelated) topics, and 2) studies which assess credibility as a construct (though not necessarily in the courtroom).

Attempting to distinguish the relative importance of various factors in judicial decision-making regarding determining primary physical residence of children of divorced parents, Sorensen and Goldman (1989) mailed surveys to judges who tried custody cases. This survey consisted of 22 questions with a 10-point Likert-type response scale. The mean responses to the items were then tallied to determine the relative weights that judges placed on the various factors.

Another judicial survey, this one attempting to determine the relative importance of various factors important in child custody cases, also used a Likert-type response scale (Lowery, 1981). The mail-in survey was then tallied and sorted according to the mean replies to the 
questions. The judges were also given the opportunity to respond to open-ended questions that were later categorized and subjected to a frequency count.

Several other studies used hypothetical situations to assess credibility. Birnbaum and stegner (1979) showed videotapes of several conditions of eyewitness testimony with accompanying expert witness testimony (relating to the eyewitness testimony) to a group of volunteer "jurors". The subjects were then asked to rate the credibility of the testimony using 10-point Likert-type response scales.

Another study using hypothetical situations had subjects read a short description of a particular communicator along with a "persuasive" argument said to have been written by the communicator (McGinnies and Ward, 1980). The subjects, college students in four countries, were then asked to rate the effectiveness of the arguments presented by the described communicator. Once again, a Likert-type response scale was used to assess the subject's feelings; though only five reference points were used for this assessment.

Likert-type response scales were used almost universally to assess subjects reactions to various communicators. Likewise, judicial surveys also frequently employed Likert-type response scales. The analysis for these studies involved tallying the mean for each item and 
comparing the items to obtain a ranking of the factors assessed. 


\section{Program of study}

This study is part of a larger program of study. The larger study will use structural equation modeling to test the proposed model. It is thought that expert witness characteristics and behaviors, in addition to "receiver" characteristics, will affect the "receivers" perceptions of expert witness credibility. It is further hypothesized that this perception of credibility will be directly related to judges concordance with expert witness recommendations. 
Figure 1 
Conclusions

Judicial perceptions of the credibility of expert witnesses determine the weight given to experts' testimony when making child custody decisions. Because expert witnesses are in a unique position to contribute to the knowledge of the court, it is vital that the expert's testimony be as credible as possible. This important link between a mental health worker's evaluation and the final custody decision has frequently been overlooked by the empirical literature.

Credibility as "a set of perceptions about sources held by receivers" (Bettinhaus, 1973, p. 134) may be thought to consist of three main components: expertise, trustworthiness, and dynamism (Bank \& Poythress, 1982). These components, in turn, may be thought to be related to credibility during all phases of an expert's testimony. These phases are: preparation, presentation, and reputation. Credibility then, may be conceptualized according to a matrix which includes this information. This $3 \times 3$ "Influence on Credibility" matrix was used to create the subjective Expert Witness Rating Form (SEWRF), a questionnaire designed to assess the components courtroom professionals find important when rating the credibility of expert witnesses. The characteristics of the "receivers" of expert witness testimony have also been shown to be important 
(Sorensen \& Goldman, 1989). To determine the importance of these characteristics in influencing courtroom professionals' perceptions of expert witnesses, several instruments were developed to assess attorneys' and judges' knowledge of psychological processes relevant to custody decisions. Traditional court and family attitudes are also assessed. In addition, demographic information of the attorneys and judges has been collected.

Clearly, expert witness evaluations are an important topic to address. If done appropriately and presented credibly, such evaluations may offer much to the judges deciding child custody and visitation cases. The information potentially available to and organized by the expert witness may greatly aid the judge to make a more informed custody decision.

The goal of this study is to determine how attorneys and judges perceive expert witness testimony and to establish those variables that affect their perception of the credibility of this testimony. The subjective Expert Witness Rating Form was designed to assess those factors attorneys and judges deem important in deciding expert witness credibility. Determination of receiver characteristics was accomplished by gathering demographic, attitudinal, and fund of knowledge information about the receivers. Further, it is thought that by tying this 
assessment to actual custody cases, error associated with abstraction from hypothetical concepts may be avoided.

This investigation is the basis for a larger program of study that will build upon its findings. In addition to confirming the findings of this study, the proposed model will assess how expert characteristics and behaviors affect the child custody process. 
Method

Subjects

Subjects were a portion of all Virginia attorneys who wished to become certified as guardians ad litem. Attorneys attending a daylong training seminar on issues relating to guardians at litem were asked to complete a six-page questionnaire. Additionally, information was also gathered from judges who attend the seminars. Over 1,000 judges and lawyers attend the seminars. Of these, 381 had time to complete the questionnaires before the seminar began. Instruments.

Demographic and Attitudinal Questionnaire (DAQ).

The DAQ assesses demographic information and information such as years since law school, custody related training and experience, attitudes toward expert witnesses, etc. Each participating attorney was asked to fill out this questionnaire at the beginning of the seminar. This instrument was used to describe the sample of attorneys in this study.

Subjective Expert Witness Rating Form (SEWRF).

The SEWRF assesses attorney and judicial perceptions of the credibility of expert witnesses in child custody cases. Factors important in the formation of judicial perceptions 
of expert witness credibility can be conceptualized according to a $3 \times 3$ "Influence on Credibility" matrix. This matrix consists of the components thought to comprise credibility (expertise, trustworthiness, and dynamism) (Bettinhaus, 1973, p. 134) across all aspects of an expert's testimony (preparation, presentation, and reputation). The Influence on Credibility Matrix was used to design items to assess perceptions of expert witness credibility on the Subjective Expert Witness Rating Form. Items are assessed according to a likert-type format ranging from 1 (strongly disagree) to 5 (strongly agree). Sample items include: The evaluation included family observations in a broad range of settings.

The expert used inappropriate assessment techniques.

Traditional Court and Family Attitude Form TCFAF.

The TCFAF was designed to assess attorney and judicial views toward traditional court and family structures. It consists of 18 items assessing attitudes toward custody decision-making and family organization. Attitudes are assessed according to a Likert-type format ranging from 1 (strongly disagree) to 5 (strongly agree). Sample items include:

The adversarial nature of the courtroom is the most effective setting to ensure informed decisions in custody and visitation cases. 
The traditional nuclear family is the best place to raise children.

Knowledge Assessment Form (KAF)

The KAF was designed to assess attorney and judicial knowledge about four important dimensions relation to children. These dimension are: 1) knowledge of the divorce adjustment process, 2) knowledge of child developmental milestones, 3) knowledge of information related to child abuse, and 4) knowledge of parenting characteristics. The questions are multiple choice. Sample items include:

It usually takes about for families to complete the divorce adjustment process.
A. 1 year
B. 2 years
C. 5 years
D. 10 years

Permissive parents generally have children who are
A. honest
B. creative
C. obedient
D. impulsive

Procedures.

Approximately 1,000 Virginia attorneys wishing to be certified as guardians ad litem in the Commonwealth of Virginia were asked to participate in the study. All such attorneys are required to attend a daylong seminar on matters related to guardians ad litem. The attorneys were asked to complete the six-page questionnaire before the seminar began. A total of 381 subjects returned the questionnaire packet. 
Upon entering the seminar, each attorney was given an assessment packet and asked to complete it before the seminar began. Immediately prior to the beginning of the seminar presentations, the packets were collected from all attorneys who were able to complete the questionnaires. 
Results

The primary goals of the current study were to assess the psychometric properties of the Subjective Expert Witness Rating Form (SEWRF), the Traditional Court and Family Assessment Form (TCFAF), and the Knowledge Assessment Form (KAF). Additionally, the contributions of several variables were examined to determine their influence on perceptions of expert witness credibility in child custody cases. Data were analyzed in three steps. First, the internal reliability of the instruments were examined to determine overall item selection and to ensure the development of adequate scales. To determine how closely the scales on the two opinion instruments matched the hypothesized constructs, factor analyses were performed. Second, the items on the Subjective Expert Witness Rating Form were examined to determine which items were most associated with lawyers' and judges' perceptions of expert witness credibility in child custody cases. Last, relationships among the scales were examined to identify those factors and processes which are most important in determining both specific and general appraisals of expert witness credibility. The influence of certain demographic information on the appraisal of expert witnesses was also examined. 
In an effort to examine the psychometric properties of the various instruments, Chronbach's alpha statistics were run on the two opinion questionnaires. Item analyses were conducted to determine the final composition of the objective and factual knowledge questionnaire. Factor analyses were performed on both the SEWRF and TCFAF. Number of factors and loading of each item on the factors was examined.

To determine those items most important to lawyers' and judges' perceptions of expert witnesses, a multiple regression analysis was run with the items in the SEWRF predicting overall appraisal of credibility. The semipartial correlations were examined to ascertain which items contributed the most variance associated with expert witness credibility.

Relationships among scales and demographic variables were determined by examining correlations and multiple regressions between the variables. The relative contributions of each variable to attorney's and judges' perceptions of the credibility of expert witnesses (SEWRF composite score) were determined. These scales were the Expertise, Trustworthiness, and Dynamism scales of the SEWRF, the Traditional Family Attitudes and the Traditional Court Attitudes of the TCFAF, and the Knowledge Assessment Form. The influence of these variables on both specific and 
general perceptions of expert witnesses was examined. The demographic variables of the subjects were race, gender, number of years since receiving law degree, number of custody disputes in which they have been involved, and number of workshops relating to child custody and divorce that they have taken.

Subjective Expert Witness Rating Form (SEWRF).

Reliability statistics performed on the SEWRF revealed an overall coefficient alpha of 0.92 . The SEWRF was designed to assess expert witness credibility along three dimensions thought to be related to credibility: Expertise, Trustworthiness, and Dynamism. Coefficient alphas for the three scales are, respectively, 0.79, 0.83, and 0.74. Correlations between the various scales revealed that the scales were not orthogonal. Expertise was strongly positively related to both Trustworthiness $(\underline{r}=.702)$ and Dynamism $(\underline{r}=.643)$, while Trustworthiness and Dynamism were also strongly correlated $(\underline{r}=.592)$. The three scales of Expertise, Trustworthiness, and Dynamism were all very strongly correlated with the SERWF composite score ( $\underline{r}=.908$, .879, and .798, respectively). 
Table 1

Correlations between the scales of the SEWRF and the SEWRF_ Composite score

\begin{tabular}{|c|c|c|c|}
\hline Expertise & $\begin{array}{c}\text { Expertise } \\
1.000\end{array}$ & Trustworthiness & Dynamism \\
\hline Trustworthiness & $.702 * \star$ & 1.000 & \\
\hline Dynamism & $.643 * \star$ & $.592 *$ * & 1.000 \\
\hline Composite Score & $.908 * \star$ & $.897 * \star$ & $.798 * \star$ \\
\hline
\end{tabular}


Examination of the Cronbach's alpha for each scale revealed that the elimination of any item would not significantly increase internal consistency. As a result all original items were kept. The SEWRF contains a total of 19 items, with the Expertise scale being composed of 7 items, the Trustworthiness scale comprising 6 items, and the Dynamism scale containing 5 items. The additional item is a general measure of the perception of expert witness credibility and is not subsumed under any scale. 
Table 2

Items and Reliability Estimates for the Scales of the SEWRF

Expertise Scale (Chronbach's $\alpha=.787$ )

2. All children, both parents, and other relevant caretakers were included in the evaluation.

3. The evaluation included family

observations in a broad range of settings.

4. The expert was familiar with the laws, statutes, and regulations relevant to child custody cases.

7. The expert was well-qualified to testify.

8. The expert was familiar with the use and interpretation of standardized assessment techniques.

9. The expert used inappropriate assessment techniques. (reverse scored)

15. The expert had a reputation for being well-qualified to testify in child custody cases.
Scale $\alpha$ if Item Removed .761

.789

.779

.729

.756

.757 518

Total corr. 
Table 2 (continued)

Dynamism Scale (Chronbach's $\alpha=.743$ )

Scale $\alpha$

Item/

if Item

Total

Removed

Corr.

10. The expert seemed ill-prepared. (reverse)

.714

.475

12. The testimony was presented in an organized and logical manner.

13. The expert's manner during crossexamination was similar to his/her manner during direct examination.

14. The expert's testimony was engaging.

18. The expert had a reputation as a dull speaker. (reverse) 
Principle components analysis of the SEWRF revealed three distinct factors with Eigenvalues above 1.00. The factors were subjected to a non-orthogonal rotation resulting in loadings for each item on each of the three factors. Examination of the items with the highest loadings on each factor revealed that 11 of the 18 items loaded onto the factors as hypothesized. 
Table 3

Principal Components Analyses of the SEWRF:

Rotated Factor Matrix

\section{Item Hypothesized Factor 1 Factor loadings}

1

2

4

5

6

7

8

9

10

11

12

13

14

15

16 Trustworthiness

17 Trustworthiness

18 Dynamism
Factor 2

loadings

.025

.133

.094

.446

.005

.189

.627

.700

.385

.591

.147

.775

.369

.628

.662

.238

.332

.259
Factor 3

loadings

.675

.685

.786

.786

.423

.383

.223

.115

.299

.416

.449

$-.065$

.062

.130

.042

.007

.158

.058

Note: Items with largest loadings on each factor are in bold. 
Traditional Court and Family Assessment Form (TCFAFL.

The overall Cronbach's alpha for the TCFAF was 0.73 .

The TCFAF was composed of two subscales: Traditional Court Attitudes (TCA) and Traditional Family Attitudes (TFA).

Alpha values for the two scales are, respectively, 0.64 and 0.68. Correlations between the two scales indicated that the scales were not orthogonal. Traditional Court Attitudes were positively correlated were Traditional Family Attitudes $(r=.348)$, and both were strongly correlated with the TCFAF composite score ( $r=.826$ and .815 respectively). 
Table 4

Scale LComposite Correlations for the

Traditional Court and Family Assessment Form (TCFAFL.

Traditional Court

Traditional Court

Traditional Family

Composite Score
1.000

$.348 * \star$

$.826 \star \star$
Traditional Family

1.000

.815 *

$\star=\underline{p} \leq .05 \quad * *=\underline{p} \leq .01$ 
Principle components analysis of the TCFAF revealed six factors with Eigenvalues above 1.00. Examination of these factors did not reveal interpretable findings so the number of factors were constrained to two in accordance with the previously hypothesized factors. The factors were subjected to a non-orthogonal rotation resulting in loadings for each item on each of the two factors. Examination of the items with the highest loadings on each factor revealed that 11 of the 18 items loaded onto the factors as hypothesized. However, several items loaded strongly on both factors while other items did not load strongly on either. 
Table 5

Principal Components Analyses of the TCFAF:

Rotated Factor Matrix

$\begin{array}{lccc}\text { Item } & \begin{array}{c}\text { Hypothesized } \\ \text { Factor }\end{array} & \begin{array}{c}\text { Factor } 1 \\ \text { loadings }\end{array} & \begin{array}{c}\text { Factor 2 } \\ \text { loadings }\end{array} \\ 1 & \text { TCA } & .251 & .167 \\ 2 & \text { TCA } & .464 & .057 \\ 3 & \text { TCA } & .212 & -.007 \\ 4 & \text { TCA } & -.335 & .002 \\ 5 & \text { TCA } & .388 & .164 \\ 6 & \text { TCA } & -.031 & .218 \\ 7 & \text { TFA } & .176 & .656 \\ 8 & \text { TFA } & .465 & .163 \\ 9 & \text { TFA } & .162 & .761 \\ 10 & \text { TCA } & -.005 & .665 \\ 11 & \text { TCA } & .180 & .049 \\ 12 & \text { TCA } & -.224 & .413 \\ 13 & \text { TCA } & .731 & -.072 \\ 14 & \text { TCA } & .559 & -.118 \\ 15 & \text { TFA } & .317 & .558 \\ 16 & \text { TCA } & .600 & . .009 \\ 17 & \text { TCA } & .692 & .083 \\ 18 & \text { TFA } & .501 & .476\end{array}$

Note. Items with largest loadings on each factor are in bold. 
The original instrument contained a total of 18 items. However, during the course of the analyses, 6 items were deleted because they lowered the internal reliability of the questionnaire. After the deletion of these poor items, the Traditional Court Attitudes scale consists of 7 items while the Traditional Family Attitudes scale consists of 5 items. 
Table 6

Items and Reliability Estimates for the Scales of the TCFAF

Traditional Court Attitudes (Chronbach's $\alpha=.640$ )

1. Mediation of custody cases is wrought with many subtle problems, and is not worth it.

2. Mothers should be given the presumption of custody.

3. In high hostility families, it is preferable to restrict the parent's direct communication about the children.

4. Joint custody should be the default custody arrangement. (reverse scored)

5. The adversarial nature of the courtroom is the most effective setting to ensure informed decisions in custody and visitation cases.

6. The court should hire one expert witness to evaluate all relevant parties in custody disputes. (reverse scored)

10. The parents' moral character should be considered in child custody cases.

11. In cases were child abuse has been alleged, only supervised visitation should be allowed.

12. Whenever possible, siblings should be kept together when deciding custody.

13. A girl should be awarded to the mother and a boy, unless he is very young, to the father.

14. The legal rights of the parents are of primary importance when deciding custody and visitation cases.

16. To maintain continuity of the relationship, the child should generally be placed with whomever was given temporary custody.

17. Custodial preference should be given to a nonworking parent.
Scale Alpha

if item

removed

.644

Item/

Total

Corr.

.236

.612

.321

Item Deleted

Item Deleted

.605

Item Deleted

Item Deleted

Item Deleted

Item Deleted 
Table 6 (continued)

Traditional Family Attitudes (Chronbach's $\alpha=.682$ )

7. Societal institutions should convey a stronger sense of traditional family values as a means of promoting more functional families and healthier children.

8. Single parent families always present insurmountable problems for children.

9. The traditional nuclear family is the best place to raise children.

15. It is very important that the custodial parent to provide religious education for the child.

18. A parent living with a boyfriend or girlfriend should be considered the custodial parent only as a last resort.
Scale Alpha

if item

removed

.614

.477

.689

.278

.609

.485

.621

.463

.612

.478

Item/

corr.

\section{7}

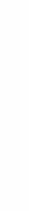


Knowledge Assessment Form (KAF).

An item analysis was performed on the KAF, comparing item means of those with total scores above the total mean with those whose total score was below the total mean. Percent correct for each group was examined. Items were deleted from the KAF if they did not distinguish the two groups by at least 10 percentage points or if at least half of the high scoring group missed the item. Out of a total of 20 original items, 6 were omitted based on the criteria outlined below. 
Table 7

Items and Item Analysis of the Knowledge Assessment Form

1. It usually takes about complete the divorce adjustment process.
A. 1 year
B. 2 years
C. 5 years
D. 10 years for families to

2. Which of the following indicators of children's mental health are mediated by age?
A. language
B. compliance with rules
C. motor control
D. all of the above

3. Highly controlling parents frequently have children who are

A.

4$$
\text { children. }
$$
A. Older parents
B. College-educated parents
C. Teen parents
D. Divorced parents

is the factor that research finds to

5 .

b

be most predictive of children's post-divorce adjustment.
A. Parental conflict
B. Father absence
C. Moving to a new home
D. Gender of the child

6. 11 to 13 year old children are most likely to conform their ideas and behaviors to the expectations of their
A. parent $\bar{s}$
B. peers
C. teachers
D. television and

film heroes

7. Permissive parents frequently have children who are

8

B. creative

C. obedient

D. impulsive are most likely to sexually abuse

children.
A. Biological fathers
B. Biological mothers
C. Step-mothers
D. Step-fathers

9. Within about a year, children of divorced parents show

A. a higher rate of behavioral problems

B. a higher rate of behavioral problems among girls

C. a higher rate of attempted suicide

D. show no differences in the rate of behavior problems
$70.6 \%$

18.8

$68.2 \%$

19.5

Average

Percent

Correct

$49.9 \%$

$27.6 \%$

$82.4 \%$

$22.0 \%$

$80.1 \%$

$15.7 \%$

$81.4 \%$

20.3

22.8

$85.0 \%$

$80.8 \%$

28.7

$12.3 \%$

1.7 
Table 7 (continued)

Average

Percent

Correct

$34.6 \%$
A. 4-6 months
C. 10-12 months
B. 8-10 months
D. 12-14 months

11. Self-reliant, self-controlled and content children

frequently have parents who are
A. permissive
C. firm but democratic
B. controlling
D. restrictive

12. The majority of physically abused children will

become abusers themselves as parents.
A. This statement is true.
B. This statement is false.
C. This statement is true for boys, but not girls.
D. This statement is true for girls, but not boys.

13. School age children of divorced parents are generally of their parents dating/sexual activities.
A. not aware
C. aware, but lacking understanding
B. aware
D. unconsciously aware

14. Most children begin crawling at what age?
A. 6-8 months
B. 8-10 months
C. 10-12 months
D. 12-14 months

15. Boys who live in father absent homes tend to be
A. more feminine than boys with live-in fathers
B. more aggressive than boys with live-in fathers
C. more dependent than boys with live-in fathers
D. more likely to be homosexual than boys with live-in fathers

16 . is most likely to cause conflict with children if they attempt to take an active role in discipline after divorce.
A. The custodial parent
C. A step-parent
B. The non-custodial parent
D. An older sibling

$23.6 \%$

7.6

$65.9 \%$

23.8

$27.3 \%$

14.8

17. Girls are most often sexually abused when they

A. are old enough to talk

$74.5 \%$

33.4

B. act seductively

C. approach adolescence in an intact home

14.1

Difference

Betweer

Groups

12.7 
D. approach adolescence in an step-family home

Table 7 (continued) C. 9-10 years B. 7-8 years

A. 5-6 years

D. 11-12 years

19. Giving children choices facilitates the development of
A. anxiety
B. free will
C. a sense of humor
D. a sense of self-efficacy and self-reliance

Average Percent Correct

$12.3 \%$

Difference Between Groups

7.6

$88.7 \%$ 14.9

$92.1 \%$

8.9

20. Verbal abuse has

A. some short-term, but few long term effects on the child's psychological health

B. no real effects on the child if the parent apologizes later

c. short-term and long-term effects on the child's self worth

D. no effect if the rest of the parent-child relationship is good

Note. Bolded items discarded before further analysis 
Subjective Expert Witness Rating Form, Item Analyses

Regression analyses on the SEWRF were examined to determine the most important items in predicting overall credibility from the scales comprising the SEWRF. Listed here are the items from each scale which have the highest semipartial correlations. For the Trustworthiness scale, the items with the highest semipartial correlations are: (Number 1) "The expert did not make attempts to include both parties in the evaluation" (reverse scored, $\underline{\mathbf{s r}}=.185$ ); (Number 6) "The conclusions included opinions that were not supported by the data" (reverse scored, $\underline{\mathbf{s r}}=.173$ ); and (Number 17) "The expert had a reputation for honesty" $(\underline{s r}=.173)$. The items with the highest semipartial correlations on the Expertise scale are: (Number 9) "The expert used inappropriate assessment techniques" (reverse scored, sr=.236); (Number 2) "All children, both parents, and other relevant caretakers were included in the evaluation" ( $\underline{\mathbf{s r}}=.195)$; and (Number 7) "The expert was wellqualified to testify" $(\underline{\mathrm{s} r}=.180)$. The most important items on the Dynamism scale are: (Number 10) "The expert seemed ill-prepared" (reverse scored, $\underline{\mathbf{s}}=.366$ ) and (Number 13) "The expert's manner during cross-examination was similar to his/her manner during direct examination" ( $\underline{s r}=.263)$. 
Table 8

Largest Item/Total correlations for the SEWRF

Scale/Items Unique contribution

to SEWRF composite

(semipartial correlations)

Expertise

$\begin{array}{rl}2 & .195 * \star \\ 3 & .095 * \star \\ 4 & .116 \star * \\ 7 & .180 \star \\ 8 & .047 \star \\ 9 & .236 \star \\ 15 & .142 \star\end{array}$

Trustworthiness

$\begin{array}{rl}1 & .185 * \text { * } \\ 5 & .100 * \text { * } \\ 6 & .173 * * \\ 11 & .155 * * \\ 16 & .166 * \star \\ 17 & .173 * *\end{array}$

Dynamism

$\begin{array}{ll}10 & .366 \star \star \\ 12 & .050 \\ 13 & .263 \star \star \\ 14 & .147 \star \star \\ 18 & .177 \star \star\end{array}$

Note. Items for each scale with highest correlation with the SEWRF composite are bolded.

$\star \underline{p} \leq .05 \quad * \star \underline{p} \leq .01$ 
Relationships Among Scales

Correlational analyses revealed that many of the scales were significantly related to each other. Traditional Court Attitudes (TCA) were significantly negatively correlated with overall perceptions of expert witnesses in child custody cases $(\underline{r}=-.134, \underline{p}<.05)$. Traditional Family Attitudes (TFA) were also significantly negatively correlated with perceptions of the expertise of expert witnesses $(\underline{r}=-.121, \underline{p}<.05)$ and with perceptions of experts' trustworthiness $(\underline{r}=-.120, \underline{p}<.05)$ as well as their overall perceptions of expert witnesses $(\underline{r}=-.149, \underline{p}<.01)$. The subjects' score on the Knowledge Assessment Form (KAF) was positively correlated with their perceptions of expert witnesses $(\underline{r}=.143, \underline{p}<.01))$, and negatively correlated with both Traditional Court and Traditional Family Attitudes ( $\underline{r}=-$ $.137, \underline{p}<.01$, and $\underline{r}=-.107, \underline{p}<.05$ respectively). 
Table 9

Correlations between the Scales on the SEWRF, TCFAF, and KAF

Expertise Trust Dynamism $\begin{gathered}\text { SEWRF } \\ \text { Composite }\end{gathered}$ KAF

$\begin{array}{lccccc}\text { TFA } & -.121 * & -.120 * & -.085 & -.149 * & -.101 * \\ \text { TCA } & -.062 & -.105 & -.105 & -.134 * & -.137 * * \\ \text { KAF } & .036 & .012 & -.026 & .143 * * & 1.000\end{array}$

* $\underline{p} \leq .05 \quad *$ * $\mathrm{p} \leq .01$

Note. TFA=Traditional Family Attitudes, TCFAF Scale TCA=Traditional Court Attitudes, TCFAF Scale 
When the Traditional Court Attitudes (TCA), Traditional Family Attitudes (TFA), and the Knowledge Assessment Form (KAF) were regressed onto specific perceptions of expert witnesses (SEWRF composite score), only the Knowledge Assessment Form was shown to share a significant amount of unique variance with the composite score ( $\underline{\mathbf{s} r}=.120, \underline{p}<.05)$. Interestingly, when these variables were regressed onto a general perception of the helpfulness of expert witnesses ("How helpful, generally, do you find expert witness testimony in child custody and visitation cases?"), only Traditional Court Attitudes evidenced a significant unique relationship with the general measure, though this relationship was negative $(\underline{\mathrm{s} r}=-.180, \underline{\mathrm{p}}<.01)$. 
Table 10

Unique Scale Contributions to the General and Specific_ Perceptions of Expert Witnesses (Semipartial Correlations).

Traditional Traditional Court Attitudes Family Attitudes
Knowledge

Assessment Form

\section{SEWRF}

Composite -.074

$-.102$

$.120 * *$

General

$-.180 * \star$

$-.022$

.053

Measure

$\star \star p \leq .01$ 
The relationship between demographic variables and subject's perceptions of expert witnesses were also examined. An analysis of variance (ANOVA) was conducted assessing the relationship between the subjects' gender, race, and religion and the composite score on the SEWRF. These variables did not differ significantly in regard to the composite SEWRF score. A similar analysis of these variables and the general measure of expert witness utility also revealed no significant differences among the groups. Multiple regression analyses were also performed. When the subject's years since receiving law degree, number of custody disputes involved in, and number of divorce and custody related workshops attended were subjected to a multiple regression analysis with the composite score on the SEWRF, only number of custody disputes and number of workshops showed significant unique contributions to the variance on the SEWRF. When the same variables were examined with regard to the general measure of expert witness credibility, only number of workshops attended showed a significant unique contribution to the variance. 
Table 11

Regression Analyses of Demographic Variables on the SEWRF_ Composite and a General Measure of Perceived Expert Witness Helpfulness (Semipartial Correlationsl.

Years

Since Receiving

Law Degree
Custody

Cases Involved in
Workshops

At tended

SEWRF

Composite $\quad-.093$

$.259 *$ *

.162 * *

General

Measure

$-.004$

$-.057$

.146 * *

$\star * \underline{p} \leq .01$ 
Discussion

Three major empirical findings are the result of the previous analyses. First, examination of reliability and factor analyses allows the development of more reliable and valid measures for model testing. Second, the tripartite theory that credibility influencers are composed of expertise, trustworthiness, and dynamism (Bank \& Poythress, 1982) has also generally been substantiated. Finally, characteristics of attorneys and judges were shown to be an important contributor to their perceptions of expert witness credibility in child custody cases. Attorneys' and judges' knowledge, attitudes, and training all play a role in affecting perceptions of expert witnesses.

The analyses of the scales for the instruments used in this study generally fit the patterns hypothesized. Item analyses for the instruments used in this study resulted in the elimination of items with poor reliability or inadequate discrimination properties. This will allow future research in the field the use of better and more reliable instruments. Principal components analyses of the two subjective instruments (SEWRF and TCFAF) resulted in factors which generally coincided with the proposed subscales of the two instruments. Perceptions of the credibility of expert 
witnesses in child custody cases may indeed be comprised of expertise, trustworthiness, and dynamism. Of these, trustworthiness appears to be the most cohesive scale, as it loads most clearly on a single factor. Further study with confirmatory factor analytic techniques is recommended to determine if the hypothesized factor structure produces a "good enough" fit with the actual data. When the number of factors on the TCFAF was constrained to two, the dimensions of traditional court attitudes and traditional family attitudes also generally fit the pattern hypothesized.

In order to be effective, the mental health professional must appear credible to the judge receiving the testimony (Skafte, 1985). Analysis of the items comprising the SEWRF suggest the following: lawyers and judges consider those experts most credible who are adequately qualified, thoroughly prepared, and fair-minded in the presentation of their findings. This finding partially corroborates Blau's (1984) finding that judges are most positively inclined towards experts who attempt to be objective.

But are these perceptions based upon the lawyers' and judges' preconceptions, or upon the actual behaviors, knowledge and presentation of the expert witnesses? It is still unclear. Moreover, the ultimate measure of potential contribution to the court's decision-making remains unassessed -- the quality of the child custody evaluation. 
It is this evaluation that will ultimately determine the degree to which an expert increases the court's likelihood of making the best child custody decision. The larger program of research outlined earlier provides a framework for separating subjective judicial perceptions from objective expert witness characteristics and professional behaviors, as well as assessing the quality of the expert's custody evaluation.

Examination of the demographic and attitudinal measures reveal that divorce and custody-related experience and training are important in determining perceptions of and, perhaps, reliance upon expert witness testimony. Increased training, knowledge, and experience in the custody and divorce arena led to increased perceptions of specific expert witness credibility. Those courtroom professionals who had greater exposure to and experiences with expert witnesses tended to view them more favorably.

However, these results may be confounded somewhat by self-selection. Those more favorably disposed towards expert witnesses may seek out experiences and training and, hence, gain greater knowledge in areas related to divorce and child custody. However, when these influences were examined with regard to general perceptions of expert witness helpfulness, only experience with custody cases was shown to positively predict general perceptions of expert 
witnesses. This suggests that those with more training and knowledge may be more receptive to what the expert in front of them is saying without making blanket assumptions about all expert witnesses. In addition, as attorneys or judges are exposed to more custody cases, they may view expert witness testimony as generally more positive.

Those attorneys and judges with more traditional court attitudes rate expert witnesses in general as less helpful. This finding builds upon two earlier studies (Foster, 1983; Sorensen \& Goldman, 1989) which showed that judicial attitudes affect their stated reliance upon psychological evaluations. Not predicted by these studies, however, is that while attorneys and judges with more traditional court attitudes did not consider expert witnesses helpful in general, they did not devalue the credibility of expert witness testimony in specific cases.

Judges admit to having significant difficulty both in weighing the wishes of the children and in reaching the best child custody decisions (Felner, Terre, Goldfarb et al., 1985; Oster, 1965). Mental health professionals may assist the court to make more knowledgeable decisions by increasing the amount of information available to the court. This information must be as complete as possible, and must be presented in a way which increases the likelihood that it will be heard and accepted. Also, to make the most informed 
decisions, judges must be able to distinguish helpful from unhelpful expert witness testimony and be in a position to utilize helpful information.

This study increases our understanding of the importance of the characteristics of lawyers and judges when determining their perceptions of expert witness credibility in child custody cases. Providing relevant training opportunities to those attorneys and judges who deal with child custody cases will enable them to better benefit from expert witness testimony. However, still missing is the determination of the importance of expert witness characteristics and their objective custody evaluation procedures. It may be that the experts are doing less than complete evaluations and their input, while credible, adds little to the fund of knowledge available to those deciding child custody cases. It is hoped that the previously outlined program of study may separate fact from pure perception and provide more specific ways for experts to structure their evaluations and testimony so it is most helpful to the judges making custody decisions. 
List of References. 


\section{References}

Anchor, K. N., \& Sieveking, N. A. (1981). Effective use of psychological testimony. Trial, 17(12), 46-49,69.

Anchor, K. N. (1984). Testifying as an expert witness. In P. Keller (Ed.), Innovations in Clinical Practice: A Source

Book: Vol. 3. (pp. 367-378). Sarasota, FL: Professional Resource Exchange.

Ash, P., \& Guyer, M. (1984). Court implementation of mental health professional's recommendations in contested child custody and visitation cases. Bulletin of the American_ Academy of Psychiatry and Law, 12, 137-147.

Bank, S. C., \& Poythress, N. G. (1982). The elements of persuasion in expert testimony. Journal of Psychiatry and Law, 10, 173-204.

Bazelon, D. L. (1975). A jurist's view of psychiatry. Journal of Psychiatry and Law, 3, 175-190.

Bettinhaus, E. (1973). Persuasive Communication (2nd ed.). New York: Holt, Rinehart, and Winston.

Birnbaum, M. H., \& Stegner, S. E. (1979). Source credibility in social judgement: bias, expertise, and the judge's point of view. Journal of Personality and Social. Psychology, 37, 48-74.

Blau, T. H. (1984). The Psychologist as Expert Witness. New York, John Wiley and Sons.

Bradbrook, A. (1971). An empirical study of the attitudes of the judges of the supreme Court of ontario regarding the working of the present child custody adjudication laws. The Canadian Bar Review, 49, 557-576.

Brodsky, S. L. (1991). Testifying in Court: Guidelines and Maxims for the Expert Witness. Washington, DC: American Psychological Association.

Conley, J. M., O'Barr, W. M., \& Lind, E. A. (1978). The power of language: presentational style in the courtroom. Duke Law Journal, 1978, 1375-1399.

Davis, V. K., \& Stolberg, A. L. (1988). Influences on professionals' child custody recommendations. Journal of Divorce, $11(3 / 4), 207-218$. 
Derdeyn, A. P. (1975). Child custody consultation. American Journal of Orthopsychiatry, 45, 791-801.

Faust, D. \& Ziskin, J. (1988). The expert witness in psychology and psychiatry. Science, 241(4861), 31-35.

Felner, R. D., Farber, S. S., Ginter, M. A., Boike, M. F., \& Cowen, E. L. (1980). Family stress and organization following parental divorce or death. Journal of Divorce, $4,67-76$.

Felner, R. D., Terre, L., Goldfarb, A., Farber, S. S., Primavera, J., Bishop, T. A., \& Aber, M. S. (1985). Party status of children during marital dissolution: child preference and legal representation in custody decisions. Journal of Child Clinical Psychology, 14, 42-48 .

Felner, R. D., Terre, L., Farber, S., Primavera, J., \& Bishop, T. A. (1985). Child custody: practices and perspectives of legal professionals. Journal of Child Clinical Psychology, 14, 27-34.

Foster, A. H. (1983). Child custody and divorce: a lawyer's view. Journal of the American Academy of Child Psychiatry, 22, 392-398.

Fox, S. G., \& Walters, H. A. (1986). The impact of general versus specific expert testimony and eyewitness confidence upon mock juror judgement. Law and Human Behavior, 10, 215-228.

Goldstein, J., Freud, A., \& Solnit, A. J. (1973). Beyond the Best Interest of the Child. New York: The Free Press.

Hetherington, E. M., Cox, M., \& Cox, R. (1976). Divorced fathers. Family Coordinator, 25, 417-428.

Hilton, O. (1968). The essence of good testimony. Medicine, Science, and the Law, 8, 85-87.

Horowitz, I. A., \& Willging, T. E. (1984). The Psychology of Law: Integrations and Applications. Boston: Little, Brown, \& Company.

Horsley, J. E., \& Carlova, J. (1983). Testifying in Court. (2nd ed.). Oradell, NJ: Medical Economic Company, Inc. 
Jacoubovitch, M. D., Bermant, G., Crockett, G. T. McKinley, W. \& Sanstad, A. (1977). Juror responses to direct and mediated presentations of expert testimony. Journal of Applied Social Psychology, 7, 227-238.

Linz, D., Penrod, S., \& McDonald, E. (1986). Attorney communication and impression making in the courtroom: views from off the bench. Law and Human Behavior, 10, 281-302.

Litwack, T. R., Gerber, G. L. \& Fenster, C. A. (1979-80). The proper role of psychology in child custody disputes. Journal of Family Law, 18, 269-300.

Lowery, C. R. (1981). Child custody decisions in divorce proceedings: a survey of judges. Professional Psychology, $12,492-498$.

Marafiote, R. A. (1985). The Custody of Children: A Behavioral Assessment Model. New York: Plenum Press. McCloskey, M., Egeth, H., McKenna, J. (1986). The experimental psychologist in court: the ethics of expert testimony. Law and Human Behavior, 10, 1-13.

McGinnies, E., \& Ward, C. D. (1980). Better liked than right: trustworthiness and expertise as factors in credibility. Personality and Social Psychology Bulletin, $6,467-472$.

Mnookin, R. H. (1975). Child-custody adjudication: judicial functions in the face of indeterminacy. Law and Contemporary Problems, 39, 226-288+ .

Naftulin, D. H., Ware, J. E., Jr., \& Donnelly, F. A. (1973). The Doctor Fox lecture: a paradigm of educational seduction. Journal of Medical Education, 48,630-635.

Nichols, J. F. (1982). The mental health professional as an expert witness. In P. A. Keller and L. G. Ritt (Eds.), Innovations in Clinical Practice: A Source Book (pp. $355-$ 362). Sarasota, FL: Professional Resource Exchange, Inc.

Okpaku, S. R. (1976). Psychology: impediment or aid in child custody cases? Rutgers Law Review, 29, 1117-1153.

Oster, A. M. (1965). Custody proceedings: a study of vague and indefinite standards. Journal of Family Law, 5, 2138 . 
Pipkin, W. E. Jr. (1989). Expert opinion testimony: experts, where did they come from and why are they here? Law and Psychology Review, 13, 101-118.

Saxe, D. B. (1975). Some reflections on the interface of law and psychiatry in child custody cases. Journal of Psychiatry and Law, 3, 501-514.

Schutz, B. M., Dixon, E. B., Lindenberger, J. C., \& Ruther, N. J. (1989). Solomon's Sword: A Practical Guide to Conducting Child Custody Evaluations. San Francisco: Jossey-Bass Inc.

Settle, S. A., \& Lowery, C. R. (1982). Child custody decisions: content analysis of a judicial survey. Journal. of Divorce, $6(1 / 2), 125-38$.

Sharf, B. F. (1986). Send in the clowns: the image of psychiatry during the Hinckley trial. Journal of Communication, 36(4), 80-93.

Skafte, D. (1985). Child Custody Evaluations: A Practical Guide. Beverly Hills: Sage Publications.

Sorensen, E., \& Goldman, J. (1989). Judicial perceptions in determining primary physical residence. Journal of_ Divorce, $12,69-87$.

Watson, A. S. (1978). On the preparation and use of psychiatric expert testimony: some suggestions in an ongoing controversy. Bulletin of the American Academy of Psychiatry and Law, 6, 226-246.

Weithorn, L. A., \& Grisso, T. (1987). Psychological evaluations in divorce custody: problems, principles, and procedures. In L. A. Weithorn (Ed.), Psychology and Child Custody Determinations: Knowledge, Roles, and Expertise. (pp. ?-??). Lincoln, NE: University of Nebraska Press.

Woocher, F. D. (1986). Legal principles governing expert testimony by experimental psychologists. Law and Human Behavior, 10, 47-61.

Wyer, M. M., Gaylord, S. J., \& Grove, E. T. (1987). The legal context of child custody evaluations. In L. A.

Weithorn (Ed.), Psychology and Child Custody Determinations: Knowledge, Roles, and Expertise (pp. 3-22). Lincoln, NE: University of Nebraska Press. 
Appendix A

Demographic and Attitudinal Questionnaire (DAQ) 
Region (please check one) Cent $\overline{r a I}$ VA Northern VA $\frac{\text { Southwestern VA }}{\text { TIdewater VA }}$ Objective Questionna1re

1. Age:

2. Sex: Male Female

3. Race: Asian American African American European American Hispanic American Native American

4. Religion:

Cathollc Jewish Protestant Not Affillated Other

5. If you are religlous, how active are you in your church?

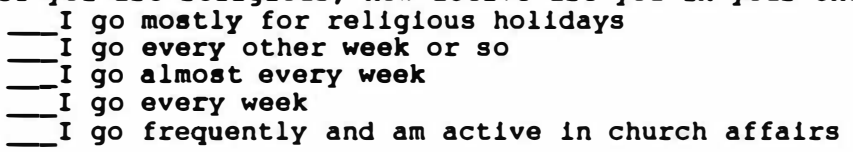

6. Position in the court (check all that apply) _-attorney _ guardian ad litem Judge

7. Years working in the Circult Court: N/A $0-5$ 6-10 $11-15$ $16+$

8. Years working in the Juvenile Domestic Relations Court: N/A $0-5 \quad 6-10 \quad 11-15 \quad 16+$

9. Years since recelving law degree:
$0-5$ 6-10
$11-15$
$16-20$
$20+$

10. Years in practice:

-0-5 $6-10$

$11-15-16-20$

$20+$

11. Approximately how many chlld custody or visitation cases have you heard or particlpated in?

0-10 $11-20$ $21-30$ $31-40$ $41+$

12. How helpful, generally, do you find expert witness testimony in child custody and visitation cases? not at all a little somewhat a $10 t$

13. How many classes or workshops on divorce and/or custody have been a formal part of your professional tralning?

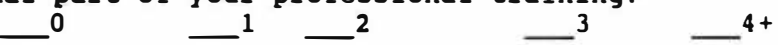

14. In general, how much of your professional time is spent in divorcerelated and/or chlld custody cases?

- 0-10: - 11-258 26-508 -51-758 -over 758

15. Approximately what percentage of the divorce work involves minor children? $0-108$ $11-258$ $26-508$ $51-758$ over 758 
16. Do you ever use experts as witnesses in your work with custody and visitation cases?

-_ye8 no

17. How many custody or visitation cases were you involved in the last 12 months?

18. In how many of these cases did you ut1lize expert witnesses?

19. Who is in the best position to determine the best arrangement for children involved in custody and visitation cases?
A. Judges
B. the parents' lawyers
C. the guardian ad litem
D. mental health experts
E. medlators

20. What role should mental health professionals have in child custody determinatlons?
A. binding recommendations to the parents
B. recommendations to the judge
C. presentation of evaluation data only
D. no role

21. In your experience, how often are expert witness recommendations followed in the final ruling?
A. $75-1008$
B. 50-74:
C. $25-498$
D. $0-248$

22. In your opinion, what percentage of expert witness recommendations are in the best interest of the child(ren).
A. $75-1008$
B. 50-748
C. $25-498$
D. $0-24$ :

23. Have you ever consulted with a mental health expert for a personal or famlly problem?

yes _no

24. When expert witnesses are used in the courtroom for chlld custody testimony, do you find that generally they
A. promote the best interest of one of the parents
B. promote the best interest of the chlldren
C. are not helpful at all
D. Other (please 11st) 
Appendix B

Subjective Expert Witness Rating Form (SEWRF) 
Subjective Expert WItness Rating Form

Using the form below, please rate your perceptions of the expert witness testifying in the nost recent custody/visitation case with which you were associated. Circle the number that best describes your amount of agreement with the statement. If you do not know a particular answer, please draw a circle around all the numbers.

$1=S$ trongly agree $2=$ Agree $3=$ Neutral 4 .Disagree 5. Strongly disagree

1. The expert did not make attempts to Include both parties in the evaluation.

2. All chlldren, both parents, and other relevant caretakers were included in the evaluation.

122345

3. The evaluation included family observations in a broad range of settings.

4. The expert was familiar with the laws, statutes, and regulations relevant to child custody cases.

5. The expert's conclusions focused more on the parents' needs and desires than the chlld's.

6. The conclusions included opinions that were not supported by the data.

$123 \quad 3 \quad 45$

7. The expert was well-qualified to testify.

8. The expert was familiar with the use and interpretation of standardized assessment techniques.

$\begin{array}{lllll}1 & 2 & 3 & 4 & 5\end{array}$

9. The expert used Inappropriate assessment techniques.

1223445

10. The expert seemed 111-prepared.

$\begin{array}{lllll}1 & 2 & 3 & 4 & 5\end{array}$

11. The expert seemed blased in $\mathrm{hls} / \mathrm{her}$ testimony.

1223045

12. The testimony was presented in an organlzed and loglcal manner.

13. The expert's manner during cross-examination was similar to $\mathrm{hls} / \mathrm{her}$ manner during direct examination.

14. The expert's testimony was engaging.

15. The expert had a reputation for being well-qualified to testify in child custody cases.

16. The expert had a reputation for being blased.

17. The expert had a reputation for honesty.

18. The expert had a reputation as a dull speaker.

19. Overall, I found this witness to be highly credible. 
Appendix C

Traditional Court and Family Assessment Form (TCFAF) 
Please rate your oplnions to the following questions by clrcling the number that best describes your amount of agreement with the statement.

\begin{tabular}{|c|c|c|c|c|}
\hline $1=$ Strongly agree & 2=Agree & $3=$ Neutral & 4.D1sagree & 5.strongly disagre \\
\hline
\end{tabular}

1. Medlation of custody cases 18 wrought with many subtle problems, and 18 not worth 1 t.

2. Mothers should be given the presumption of custody.

3. In high host1lity fam1l1es, it $1 \mathrm{~s}$ preferable to restrict the parent's direct communication about the children.

4. Jolnt custody should be the default custody arrangement.

5. The adversarial nature of the courtroom is the most effective setting to ensure informed decisions in custody and visitation cases.

6. The court should h1re one expert witness to evaluate all relevant parties in custody disputes.

7. Socletal Instltutions should convey a stronger sense of tradltional famlly values as a means of promoting more functional famliles and healthler chlldren.

8. Single parent families always present Insurmountable problems for chlldren.

9. The traditional nuclear family 18 the best place to ralse chlldren.

$\begin{array}{lllll}1 & 2 & 3 & 4 & 5\end{array}$

10. The parents' moral character should be considered in child custody cases.

11. In cases were chlld abuse has been alleged, only supervised visitation should be allowed.

12. Whenever possible, siblings should be kept together when deciding custody.

123345

13. A girl should be awarded to the mother and a boy, unless he 18 very young, to the father.

$1 \quad 2 \quad 3 \quad 456$

14. The legal rights of the parents are of primary importance when deciding custody and visitation cases.

15. It $1 \mathrm{~s}$ very Important that the custodial parent to provide religlous education for the child.

16. To maintain continuity of the relationship, the child should generally be placed with whomever was given temporary custody.

17. Custodial preference should be glven to a non-working parent.

18. A parent living with a boyfrlend or girlfriend should be considered the custodial parent only as a last resort. 
Appendix D

Knowledge Assessment Form (KAF) 
Please answer the following questions as quickly and accurately as possible. Indlcate your answer by clrcling your cholce, taking care to circle only one letter. If you do not know the answer to a particular question, please make your best guess.

1. It usually takes about adjustment process.

for families to complete the divorce
A. 1 year
B. 2 years
C. 5 years
D. 10 years

2. Which of the following indicators of children's mental health are medlated by age?
A. language
C. motor control
B. compllance w1th rules
D. all of the above

3. Highly controlling parents frequently have chlldren who are
A. cheerful
B. fearful
C. honest
D. punctual

4.
A. Older parents
B. College-educated parents
C. Teen parents
D. D1vorced parents

are more likely to abuse their children.

5. is the factor that research finds to be most predictive of children's post-divorce adjustment.
A. Parental conflict
C. Moving to a new home
B. Father absence
D. Gender of the child

6. 11 to 13 year old children are most likely to conform the1r ideas and behaviors to the expectations of their
A. parents
B. peers
C. teachers
D. television and film heroes

7. Permissive parents frequently have chlldren who are
A. honest
B. creative
C. obedient D. Impulsive

8.

are most likely to sexually abuse children.
fathers
C. Step-mothers
A. Blological fathers
B. Blological mothers
D. Step-fathers

9. Within about a year, chlldren of divorced parents show than chlldren from intact homes.
A. a higher rate of behavioral problems
B. a hlgher rate of behavioral problems among girls
C. a hlgher rate of attempted sulcide
D. show no differences in the rate of behavior problems

10. Most chlldren understand simple sentences at about what age?
A. 4-6 months
C. 10-12 months
B. 8-10 months
D. 12-14 months

11. Self-reliant, self-controlled and content children frequently have parents who are
A. permissive
C. f1rm but democratic
B. controlling
D. restrictive 
12. The mafority of physically abused children will become abusers themselves as parents.
A. This statement is true.
B. This statement is false.
C. This statement is true for boys, but not girls.
D. This statement is true for girls, but not boys.

13. School age children of divorced parents are generally of their parents dating/sexual activities.
A. not aware
C. aware, but lacking understanding
B. aware
D. unconsciously aware

14. Most children begin crawling at what age?
A. 6-8 months
B. 8-10 months
C. 10-12 months
D. 12-14 months

15. Boys who live in father absent homes tend to be
A. more feminine than boys with live-in fathers
B. more aggressive than boys with live-in fathers
C. more dependent than boys with live-in fathers
D. more likely to be homosexual than boys with live-in fathers

16 . is most likely to cause conflict with children if they attempt to take an active role in discipline after divorce.
A. The custodial parent
C. A step-parent
B. The non-custodial parent
D. An older sibling

17. Girls are most often sexually abused when they
A. are old enough to talk
B. act seductively
C. approach adolescence in an intact home
D. approach adolescence in an step-family home

18. At what age are children able to reason abstractly?
A. 5-6 years
B. 7-8 years
C. 9-10 years
D. 11-12 years

19. Giving children cholces facilitates the development of
A. anxiety
C. a sense of humor
B. free will
D. a sense of self-efficacy and self-reliance

20. Verbal abuse has
A. some short-term, but few long term effects on the child's psychological health
B. no real effects on the child if the parent apologizes later
C. short-term and long-term effects on the child's self worth
D. no effect if the rest of the parent-child relationship is good 
Attorney and Judicial Perceptions

Attorney And Judicial Perceptions of The Credibility of Expert Witnesses In Child Custody Cases Michael T. Foot Virginia Commonwealth University 
Attorney and Judicial Perceptions

Introduction

Determining custody in parental divorce involving minor children is an ever-growing problem for the legal system in America. It has been estimated that the $90^{\prime} \mathrm{s}$ will see $33 \%$ of all children in the United States experiencing the divorce of their parents before they reach the age of 18 (Norton \& Glick, 1979). Though 85-90\% of the custody decisions in these cases are decided outside of the courtroom (Felner, Terre, Farber, Primavera, \& Bishop, 1985), the approximately $10 \%$ of the cases that are adjudicated are frequently the most difficult cases. Extreme conflict between the parents, allegations of parental mental illness or child abuse, and difficult choices between equally competent parents often characterize these cases (Ash \& Guyer, 1984). To further complicate matters, the guidelines by which the court decides the adjudicated cases are poorly enunciated (Davis \& Stolberg, 19988; Felner, Terre, Farber et al., 1985; Wyer, Gaylord, \& Grove, 1987). The mental health professional, a source who may provide some guidance in matters of child and family adjustment, is relegated to a vague role in the courtroom process.

Divorce can have far reaching consequences on the 
Attorney and Judicial Perceptions

future psychological functioning of the children involved (Davis \& Stolberg, 1988; Felner, Terre, Farber et al., 1985). Reorganization of the family, if done properly, affords an opportunity to prevent the development of maladaptive behavior in children that is often associated with divorce (Felner, Terre, Farber et al., 1985). The process and outcome of the child custody arrangements is an integral part of this reorganization (Felner et al., 1980). The social, emotional, and cognitive development of children at two years following divorce has been shown to be much more strongly related to the characteristics of the custodial parent, further highlighting the importance of child custody decisions (Hetherington, Cox, \& Cox, 1976). The question of how the courts may decide the optimal custodial arrangement for the child is, at best, a difficult choice which may be compounded by a high case load and the fact that judges often lack even the most basic information about the child or parent's life (Mnookin, 1975). History of Custodial Presumption

Historically, questions of custody were rarely debated since children had no rights and were considered the property of their fathers (Foster, 1983; Oster, 1965). By the twentieth century, nominal equality was established, though the presumption of custody now fell to the mother, 
Attorney and Judicial Perceptions

especially if the child was very young (Foster, 1983; Oster, 1965). More recently, the acknowledge standard has become the "best interest of the child" (Mnookin, 1975). Yet, professionals on all sides of the issue are uncertain as to what exactly "best interest" means. There has been considerable debate as to whether the "best interest" means the current or future happiness of the child, the spiritual or religious training given to the child, the projected economic productivity of the child, or the stability or intellectual stimulation available to the child (Mnookin, 1975). Whatever the definition of "best interest", the information necessary to make a sound and responsible child custody determination is not readily apparent. Most states lack any specific criteria for determining best interest of the child, and those that do often fail to specify weights or priorities among the various criteria (Wyer et al., 1987). "Unsubstantiated assumptions and presumptions, inconsistent case law, vague and indefinite statutes and criteria and personal biases" (Marafiote, 1985, p. 4) are often used by judges as bases for their custody decisions. The importance of custody decisions and the vagaries of custody guidelines for judges has led one justice to state that "a judge agonizes more about reaching the right result in a contested custody issue than about any other type of 
Attorney and Judicial Perceptions

decision he renders" (Botein in Oster, 1965, p. 23).

It is here that the psychologist or mental health worker may be able to assist the legal arena in its decision-making. Mental health experts are in a position to supply the court with additional information about the family members involved in the custody dispute and research findings relating to post-divorce adjustment. Though criticisms of mental health professionals as expert witnesses are not uncommon (Faust \& Ziskin, 1988; Okpaku, 1976), the use of psychological testimony is becoming increasingly accepted (McCloskey, Egeth, \& McKenna, 1986). The skills that psychologists may bring to the legal arena are those of "interviewer; observer; structurer and organizer of observed interactions (e.g., family interactions); administrant and interpreter of specialized assessment techniques; and conceptual organizer and interpreter of disparate and diverse supplementary data sources (e.g., school, medical, employment, social service, or court records)" (Weithorn \& Grisso, 1987, p. 170-71).

While psychologists in the courtroom have been criticized for the excessive generality of their beliefs (Litwack, Gerber, \& Fenster, 1979-80), a lack of empirical data about how adult behavior affects children (Litwack et al., 1979-80), and insufficient research into the effects of 
Attorney and Judicial Perceptions

various types of custodial arrangements (Weithorn \& Grisso, 1987), the more expansive view holds that psychologists are in a position to increase the amount of information available to the court. Indeed, it has been argued that: the issue is not whether psychologists or psychiatrists can predict the outcome of alternative custody arrangements with anything approaching absolute accuracy, but whether psychological testimony can provide the court with information, not otherwise readily available to the court, which will increase, however slightly, the accuracy of the prediction the court must make (Litwack et al., 1979-80, p. 283 ).

In order to be acceptable in court, the 1975 Federal Rules of Evidence hold that expert testimony must "assist the trier of fact to understand the evidence or to determine a fact in issue" (Rule 702). Perhaps the most succinct test of the worth of psychological testimony was written by U.S. Circuit Court Judge David L. Bazelon and states that testimony should be allowed that "will be likely to aid the trier in the search for the truth" (Jenkins v. U.S. (1962) in Horowitz \& Willging, 1984).

Psychologists in the courtroom are, therefore, in a position to impress upon the court the necessity of safeguarding the child's psychological well-being, a concern 
Attorney and Judicial Perceptions

that decision makers have been slow to take into account (Goldstein, Freud, \& Solnit, 1973). In addition to their observational training, psychologists may also inform the courts of research related to custody decisions (Weithorn \& Grisso, 1987). For example, judges and lawyers admit to having significant difficulty weighing and interpreting the wishes of the child (Felner, Terre, Goldfarb, Farber, Primavera, Bishop, \& Aber, 1985). Psychologists may inform the courts of their knowledge of child development as an aid to deciding how to best interpret the wishes of different children of different ages. Psychologists may also help to clarify the child's feelings and make these feelings more coherent to the court.

Psychologists in the Courtroom

For cases that are adjudicated, mental health professionals are often called to testify in court. As previously stated the mental health professional is in a good position to increase the knowledge available to the court, and thus it is important that this testimony be effective and worthwhile. In order to be effective, the mental health professional must appear credible to the judge (Skafte, 1985). If the expert's testimony is not credible, the court's knowledge of the psychosocial issues relating to the case may not be increased. Credibility is an important 
Attorney and Judicial Perceptions

link between the information of the expert witness and the court's decision-making process, therefore, this study will elucidate the processes that influence expert witness' credibility in the courtroom.

Far too often, mental health workers are not be properly trained to testify in court. One psychologist familiar with testifying in the courtroom warns that "expert witness roles call for attitudes, outlooks, and behaviors that are different from most mental health professional roles" (Brodsky, 1991, p. 133). Such a drastic shift of function may confuse the mental health professional not familiar with the courtroom, thus reducing his or her effectiveness in the legal arena. The literature on credibility and effectiveness of the mental health professional in the courtroom addresses how the expert may be most effective, and may be thought of as being composed of several layers: preparation, presentation, and reputation. Preparation

One aspect of credibility in the courtroom is thought to be related to the psychological "wholeness" of the mental health professional's information (Watson, 1978). An expert witness may only impart psychologically whole information to the court if he or she has properly prepared. Preparation 
Attorney and Judicial Perceptions

may be thought of as including the following: a clear delineation of the expert's role, a thorough evaluation, a well-written report, and familiarity with court layout and procedure.

Presentation

The importance of making a good first impression is well established. Expert witnesses too need to make a good impression on the judge to be most effective. One of the first things the judge will know about the witness is how they are dressed. Those familiar with the courtroom point out the necessity of professional dress with an absence of distracting accessories (Blau, 1984; Brodsky, 1991; Horsley \& Carlova, 1983; Nichols, 1982). Actions of the expert unrelated to the testimony are also thought to influence the impression the witness makes upon the judge. When the expert is being sworn in, he or she should take the oath "clearly and formally" (Horsley \& Carlova, 1983, p.59). After being sworn in and seated, the expert should turn and acknowledge the judge with a simple "good morning your honor" (Blau, 1984). Good posture, with feet placed flat on the floor, is thought to increase perception of control in the witness, and translate into a more effective bearing (Brodsky, 1991; Horsley \& Carlova, 1983). When answering questions, initiating eye contact and addressing the judge 
Attorney and Judicial Perceptions

is hypothesized to increase attention of the judge and allow the expert to better gauge if the testimony is being fully understood (Anchor \& Sieveking, 1981; Brodsky, 1991; Schutz et al., 1989). More generally, remembering that personal characteristics and relational skills are thought to be very important in other's perception of testimony, may help the expert maximize effectiveness and credibility (Linz, Penrod, \& McDonald, 1986; Pipkin, 1989).

Reputation

Though often overlooked in the literature, the credibility of an expert witness may be affected by the previous behavior of the witness. The reputation of an evaluator as a "hired gun" may precede the witness into the courtroom, and negatively impact his or her credibility with the judge (Horsley \& Carlova, 1983; Skafte, 1985). Even the behavior of others in the field may affect the general perception of the credibility of mental health professionals, as was shown by the public's negative perception of psychiatrists during John Hinckley's trial after he attempted to assassinate Ronald Reagan (Sharf, $1986)$.

The qualifications of the expert will also affect his or her credibility. Before testifying as an expert witness, a mental health professional should have demonstrated 
Attorney and Judicial Perceptions

advanced training and experience in the field (generally a doctorate), published research in the area, and studied the work of other relevant authors (Anchor \& Sieveking, 1981; Horsley \& Carlova, 1983; Woocher, 1986). Professional recognition, board certification, and membership in meaningful professional associations is also thought to positively contribute to the credibility of the expert (Horsley \& Carlova, 1983).

Empirical literature

The bulk of the previous section, while helpful in hypothesizing the contributing factors to the credibility and effectiveness of expert witnesses, is composed mostly of practical (non-empirical) information by those familiar with mental health professionals in the courtroom. There is also an empirical body of evidence which may be applied either directly or indirectly to the credibility of expert witnesses.

Credibility has been described as being composed of three components: expertise (training, experience, and other indices of professional competence), trustworthiness (apparent honesty and objectivity of witness), and dynamism (presentational style) (Bank \& Poythress, 1982). Several studies have been done attempting to determine the relative importance of the various factors. 
Attorney and Judicial Perceptions

The relative importance of trustworthiness and expertise was tested by presenting college students from four different countries with a written argument accredited to writers of varying trustworthiness and expertise. The researchers found that the argument credited to the trustworthy sources were consistently rated more favorably than the untrustworthy ones, regardless of expertise (MCGinnies \& Ward, 1980).

In contrast to this finding, another study attempting to distinguish between the effects of expertise and bias, found that "the weight of a source's communication depends mostly on the source's expertise, but diminishes if the source is biased" (Birnbaum \& Stegner, 1979, p. 72).

Dynamic testimony was the focus of a study in which an actor was presented as an expert, and spoke dynamically to a group of highly trained professional educators (Naftulin, Ware, \& Donnelly, 1973). However, he had been instructed to use "excessive double talk, neologisms, non sequiturs, and contradictory statements" (Naftulin et al., 1973, p. 631). After the lecture, the unsuspecting educators gave "Dr. Fox" more favorable than unfavorable reviews. Even for the educators, assumptions of credibility outweighed any objective examination of the lecture.

Further highlighting the importance of presentation in 
Attorney and Judicial Perceptions

determining credibility, direct testimony was found to be better retained and more persuasive than the same testimony read by an attorney (Jacoubovitch, Bermant, Crockett, McKinley, \& Sanstad, 1977). Jurors reported more reliance upon, and higher confidence in specific testimony that spelled out the factors highly relevant to the case being tried than they did to general testimony which outlined the basic processes relevant to the type of situation explained (Fox \& Walters, 1986).

"Powerful" speech, that uses fewer hedges ("I think","it seems like"), hesitation forms ("um", "well"), polite forms ("sir", "please"), less question intonation (declarative statement with rising intonation so as to convey uncertainty), and fewer overused intensifiers ("very", "surely") was found to be more convincing than "powerless" speech (Conley, O'Barr, \& Lind, 1978). Additionally, witnesses who used long narrative answers to questions from lawyers were rated as more competent when compared to witnesses using a more fragmented delivery (Conley et al., 1978).

Taken together, it may be hypothesized that, testimony that is direct, narrative, "powerful", dynamic, unbiased, trustworthy and expert will be rated more favorably than testimony that is not all of the above. 
Attorney and Judicial Perceptions

Judicial views.

Another definition of credibility is that it is "a set of perceptions about sources held by receivers" (Bettinhaus, 1973, p. 134). Because judges are the primary "receivers" of expert testimony, it is important to consider their view of mental health professionals in the courtroom. Judges asked to rate twenty items pertaining to their decisionmaking in child custody cases rated "professional advice" as the twelfth most important item on the list (Lowery, 1981), suggesting that the findings of expert witnesses were given a moderate amount of consideration. This finding was supported by another study on judicial attitudes towards expert witnesses (Sorensen \& Goldman, 1989).

However, when judges' custody decisions were compared to the recommendations of mental health evaluators in ninety-two custody cases, it was found that the court agreed with the custody evaluator's report $92 \%$ of the time (Ash \& Guyer, 1984). This should not be surprising given that judges and mental health professionals generally agree on what is important in child custody cases (Settle \& Lowery, 1982). It may be that judges do not like to presume reliance upon expert witnesses, but credible evaluators can present information to the judge that he or she will accept as reasonable. 
Attorney and Judicial Perceptions

Judicial reactions to expert testimony have also been shown to be affected by the judges' training, background, and experience (Foster, 1983). For example, liberal judges in a study of custody decisions tended to place more weight on psychological evaluations and less on the social deviance of the parents (Sorensen \& Goldman, 1989).

Conclusions

Judicial perceptions of the credibility of expert witnesses determine the weight given to experts' testimony when making child custody decisions. Because expert witnesses are in a unique position to contribute to the knowledge of the court, it is vital that the expert's testimony be as credible as possible. This important link between a mental health worker's evaluation and the final custody decision has frequently been overlooked by the empirical literature.

Credibility as "a set of perceptions about sources held by receivers" (Bettinhaus, 1973, p. 134) may be thought to consist of three main components: expertise, trustworthiness, and dynamism (Bank \& Poythress, 1982). These components, in turn, may be thought to be related to credibility during all phases of an expert's testimony. These phases are: preparation, presentation, and reputation. Credibility then, may be conceptualized according to a 
Attorney and Judicial Perceptions

matrix which includes this information. This $3 \times 3$ "Influence on Credibility" matrix was used to create the Subjective Expert Witness Rating Form (SEWRF), a questionnaire designed to assess the components courtroom professionals find important when rating the credibility of expert witnesses. The characteristics of the "receivers" of expert witness testimony have also been shown to be important (Sorensen \& Goldman, 1989). To determine the importance of these characteristics in influencing courtroom professionals' perceptions of expert witnesses, several instruments were developed to assess attorneys' and judges' knowledge of psychological processes relevant to custody decisions. Traditional court and family attitudes are also assessed. In addition, demographic information of the attorneys and judges has been collected.

Clearly, expert witness evaluations are an important topic to address. If done appropriately and presented credibly, such evaluations may offer much to the judges deciding child custody and visitation cases. The information potentially available to and organized by the expert witness may greatly aid the judge to make a more informed custody decision.

The goal of this study is to determine how attorneys and judges perceive expert witness testimony and to 
Attorney and Judicial Perceptions

establish those variables that affect their perception of the credibility of this testimony. The Subjective Expert Witness Rating Form was designed to assess those factors attorneys and judges deem important in deciding expert witness credibility. Determination of receiver characteristics was accomplished by gathering demographic, attitudinal, and fund of knowledge information about the receivers. Further, it is thought that by tying this assessment to actual custody cases, error associated with abstraction from hypothetical concepts may be avoided.

This investigation is the basis for a larger program of study that will build upon its findings. In addition to confirming the findings of this study, the proposed model will assess how expert characteristics and behaviors affect the child custody process.

Method

Subjects

Subjects were a portion of all Virginia attorneys who wished to become certified as guardians ad litem. Attorneys attending a daylong training seminar on issues relating to guardians at litem were asked to complete a six-page questionnaire. Additionally, information was also gathered from judges who attend the seminars. Over 1,000 judges and lawyers attend the seminars. Of these, 381 had time to 
Attorney and Judicial Perceptions

complete the questionnaires before the seminar began. Instruments.

Demographic and Attitudinal Questionnaire (DAQ).

The DAQ assesses demographic information and information such as years since law school, custody related training and experience, attitudes toward expert witnesses, etc. Each participating attorney was asked to fill out this questionnaire at the beginning of the seminar. This instrument was used to describe the sample of attorneys in this study.

Subjective Expert Witness Rating Form (SEWRF).

The SEWRF assesses attorney and judicial perceptions of the credibility of expert witnesses in child custody cases. Factors important in the formation of judicial perceptions of expert witness credibility can be conceptualized according to a 3 x 3 "Influence on Credibility" matrix. This matrix consists of the components thought to comprise credibility (expertise, trustworthiness, and dynamism) (Bettinhaus, 1973, p. 134 ) across all aspects of an expert's testimony (preparation, presentation, and reputation). The Influence on Credibility Matrix was used to design items to assess perceptions of expert witness credibility on the Subjective Expert Witness Rating Form. Items are assessed according to a Likert-type format ranging from 1 (strongly 
Attorney and Judicial Perceptions

disagree) to 5 (strongly agree).

Traditional Court and Family Attitude Form TCFAF

The TCFAF was designed to assess attorney and judicial views toward traditional court and family structures. It consists of 18 items assessing attitudes toward custody decision-making and family organization. Attitudes are assessed according to a Likert-type format ranging from 1 (strongly disagree) to 5 (strongly agree).

Knowledge Assessment Form (KAF).

The KAF was designed to assess attorney and judicial knowledge about four important dimensions relation to children. These dimension are: 1) knowledge of the divorce adjustment process, 2) knowledge of child developmental milestones, 3) knowledge of information related to child abuse, and 4) knowledge of parenting characteristics. The questions are multiple choice.

Procedures

Approximately 1,000 Virginia attorneys wishing to be certified as guardians ad litem in the Commonwealth of Virginia were asked to participate in the study. All such attorneys are required to attend a daylong seminar on matters related to guardians ad litem. The attorneys were asked to complete the six-page questionnaire before the seminar began. A total of 381 subjects returned the 
Attorney and Judicial Perceptions

questionnaire packet.

Results

The primary goals of the current study were to assess how attorney and judicial attitudes influenced their perceptions of expert witnesses in child custody cases. Relationships among the scales were examined to identify those factors and processes which are most important in determining both specific and general appraisals of expert witness credibility. The influence of certain demographic information on the appraisal of expert witnesses was also examined.

Relationships among scales and demographic variables were determined by examining correlations and multiple regressions between the variables. The relative contributions of each variable to attorney's and judges' perceptions of the credibility of expert witnesses (SEWRF composite score) were determined. These scales were the Expertise, Trustworthiness, and Dynamism scales of the SEWRF, the Traditional Family Attitudes and the Traditional Court Attitudes of the TCFAF, and the Knowledge Assessment Form. The influence of these variables on both specific and general perceptions of expert witnesses was examined. The demographic variables of the subjects were race, gender, number of years since receiving law degree, number of 
Attorney and Judicial Perceptions

custody disputes in which they have been involved, and number of workshops relating to child custody and divorce that they have taken.

Relationships Among Scales

Correlational analyses revealed that many of the scales were significantly related to each other. Traditional Court Attitudes (TCA) were significantly negatively correlated with overall perceptions of expert witnesses in child custody cases $\left(\underline{r}=-.134, \underline{p}^{<.05}\right)$. Traditional Family Attitudes (TFA) were also significantly negatively correlated with perceptions of the expertise of expert witnesses $(\underline{r}=-.121, \underline{p}<.05)$ and with perceptions of experts' trustworthiness $(\underline{r}=-.120, \underline{p}<.05)$ as well as their overall perceptions of expert witnesses $(\underline{r}=-.149, \underline{p}<.01)$. The subjects' score on the Knowledge Assessment Form (KAF) was positively correlated with their perceptions of expert witnesses $(\underline{r}=.143, \underline{p}<.01))$, and negatively correlated with both Traditional Court and Traditional Family Attitudes ( $\underline{r}=-$ $.137, \underline{\mathrm{p}}<.01$, and $\underline{\mathrm{r}}=-.107, \mathrm{p}<.05$ respectively).

\section{Insert Table 1 about here}

When the Traditional Court Attitudes (TCA), Traditional Family Attitudes (TFA), and the Knowledge Assessment Form 
Attorney and Judicial Perceptions

(KAF) were regressed onto specific perceptions of expert witnesses (SEWRF composite score), only the Knowledge Assessment Form was shown to share a significant amount of unique variance with the composite score ( $\underline{s r}=.120, \underline{p}<.05)$. Interestingly, when these variables were regressed onto a general perception of the helpfulness of expert witnesses ("How helpful, generally, do you find expert witness testimony in child custody and visitation cases?"), only Traditional Court Attitudes evidenced a significant unique relationship with the general measure, though this relationship was negative. $\left(\underline{s r}=-.180, p^{<} .01\right)$.

Insert Table 2 about here

The relationship between demographic variables and subject's perceptions of expert witnesses were also examined. An analysis of variance (ANOVA) was conducted assessing the relationship between the subjects' gender, race, and religion and the composite score on the SEWRF. These variables did not differ significantly in regard to the composite SEWRF score. A similar analysis of these variables and the general measure of expert witness utility also revealed no significant differences among the groups. Multiple regression analyses were also performed. When the 
Attorney and Judicial Perceptions 108

subject's years since receiving law degree, number of custody disputes involved in, and number of divorce and custody related workshops attended were subjected to a multiple regression analysis with the composite score on the SEWRF, only number of custody disputes and number of workshops showed significant unique contributions to the variance on the SEWRF. When the same variables were examined with regard to the general measure of expert witness credibility, only number of workshops attended showed a significant unique contribution to the variance.

Insert Table 3 about here

\section{Discussion}

The tripartite theory that credibility influencers are composed of expertise, trustworthiness, and dynamism (Bank \& Poythress, 1982) has also generally been substantiated. Additionally, characteristics of attorneys and judges were shown to be an important contributor to their perceptions of expert witness credibility in child custody cases. Attorneys' and judges' knowledge, attitudes, and training all play a role in affecting perceptions of expert witnesses.

Examination of the demographic and attitudinal measures reveal that divorce and custody-related experience and 
Attorney and Judicial Perceptions

training are important in determining perceptions of and, perhaps, reliance upon expert witness testimony. Increased training, knowledge, and experience in the custody and divorce arena led to increased perceptions of specific expert witness credibility. Those courtroom professionals who had greater exposure to and experiences with expert witnesses tended to view them more favorably.

However, these results may be confounded somewhat by self-selection. Those more favorably disposed towards expert witnesses may seek out experiences and training and, hence, gain greater knowledge in areas related to divorce and child custody. However, when these influences were examined with regard to general perceptions of expert witness helpfulness, only experience with custody cases was shown to positively predict general perceptions of expert witnesses. This suggests that those with more training and knowledge may be more receptive to what the expert in front of them is saying without making blanket assumptions about all expert witnesses. In addition, as attorneys or judges are exposed to more custody cases, they may view expert witness testimony as generally more positive.

Those attorneys and judges with more traditional court attitudes rate expert witnesses in general as less helpful. This finding builds upon two earlier studies (Foster, 1983; Sorensen \& Goldman, 1989) which showed that judicial 
Attorney and Judicial Perceptions

attitudes affect their stated reliance upon psychological evaluations. Not predicted by these studies, however, is that while attorneys and judges with more traditional court attitudes did not consider expert witnesses helpful in general, they did not devalue the credibility of expert witness testimony in specific cases.

Judges admit to having significant difficulty both in weighing the wishes of the children and in reaching the best child custody decisions (Felner, Terre, Goldfarb et al., 1985; Oster, 1965). Mental health professionals may assist the court to make more knowledgeable decisions by increasing the amount of information available to the court. This information must be as complete as possible, and must be presented in a way which increases the likelihood that it will be heard and accepted. Also, to make the most informed decisions, judges must be able to distinguish helpful from unhelpful expert witness testimony and be in a position to utilize helpful information.

This study increases our understanding of the importance of the characteristics of lawyers and judges when determining their perceptions of expert witness credibility in child custody cases. Providing relevant training opportunities to those attorneys and judges who deal with child custody cases will enable them to better benefit from expert witness testimony. However, still missing is the 
Attorney and Judicial Perceptions

determination of the importance of expert witness

characteristics and their objective custody evaluation procedures. It may be that the experts are doing less than complete evaluations and their input, while credible, adds little to the fund of knowledge available to those deciding child custody cases. It is hoped that the previously outlined program of study may separate fact from pure perception and provide more specific ways for experts to structure their evaluations and testimony so it is most helpful to the judges making custody decisions. 
Attorney and Judicial Perceptions

\section{References}

Anchor, K. N., \& Sieveking, N. A. (1981). Effective use of psychological testimony. Trial, 17(12), 46-49,69.

Anchor, K. N. (1984). Testifying as an expert witness. In P. Keller (Ed.), Innovations in Clinical Practice: A Source Book: Vol. 3 (pp. 367-378). Sarasota, FL: Professional Resource Exchange.

Ash, P., \& Guyer, M. (1984). Court implementation of mental health professional's recommendations in contested child custody and visitation cases. Bulletin of the American AcademY of Psychiatry and Law, 12, 137-147.

Bank, S. C., \& Poythress, N. G. (1982). The elements of persuasion in expert testimony. Journal of Psychiatry and Law, 10, 173-204.

Bazelon, D. L. (1975). A jurist's view of psychiatry. Journal of Psychiatry and Law, 3, 175-190.

Bettinhaus, E. (1973). Persuasive Communication (2nd ed.). New York: Holt, Rinehart, and Winston.

Birnbaum, M. H., \& Stegner, S. E. (1979). Source credibility in social judgement: bias, expertise, and the judge's point of view. Journal of Personality and Social. Psychology, 37, 48-74.

Blau, T. H. (1984). The Psychologist as Expert Witness. New York, John Wiley and Sons.

Bradbrook, A. (1971). An empirical study of the attitudes of the judges of the Supreme Court of Ontario regarding the working of the present child custody adjudication laws. The Canadian Bar Review, 49, 557-576.

Brodsky, S. L. (1991). Testifying in Court: Guidelines and Maxims for the Expert Witness. Washington, DC: American Psychological Association.

Conley, J. M., O'Barr, W. M., \& Lind, E. A. (1978). The power of language: presentational style in the courtroom. Duke Law Journal, 1978, 1375-1399.

Davis, V. K., \& Stolberg, A. L. (1988). Influences on professionals' child custody recommendations. Journal of Divorce, 11(3/4), 207-218. 
Attorney and Judicial Perceptions

Derdeyn, A. P. (1975). Child custody consultation. American Journal of Orthopsychiatry, $\underline{45}, 791-801$.

Faust, D. \& Ziskin, J. (1988). The expert witness in psychology and psychiatry. Science, 241(4861), 31-35.

Felner, R. D., Farber, S. S., Ginter, M. A., Boike, M. F., \& Cowen, E. L. (1980). Family stress and organization following parental divorce or death. Journal of Divorce, $4,67-76$.

Felner, R. D., Terre, L., Goldfarb, A., Farber, S. S., Primavera, J., Bishop, T. A., \& Aber, M. S. (1985). Party status of children during marital dissolution: child preference and legal representation in custody decisions. Journal of Child Clinical Psychology, 14, 42-48.

Felner, R. D., Terre, L., Farber, S., Primavera, J., \& Bishop, T. A. (1985). Child custody: practices and perspectives of legal professionals. Journal of Child Clinical Psychology, 14, 27-34.

Foster, A. H. (1983). Child custody and divorce: a lawyer's view. Journal of the American Academy of Child Psychiatry, 22, 392-398.

Fox, S. G., \& Walters, H. A. (1986). The impact of general versus specific expert testimony and eyewitness confidence upon mock juror judgement. Law and Human Behavior, 10, 215-228.

Goldstein, J., Freud, A., \& Solnit, A. J. (1973). Beyond the Best Interest of the Child. New York: The Free Press.

Hetherington, E. M., Cox, M. , \& Cox, R. (1976). Divorced fathers. Family Coordinator, 25, 417-428.

Hilton, O. (1968). The essence of good testimony. Medicine, Science, and the Law, 8, 85-87.

Horowitz, I. A., \& Willging, T. E. (1984). The Psychology of Law: Integrations and Applications. Boston: Little, Brown, \& Company.

Horsley, J. E., \& Carlova, J. (1983). Testifying in Court (2nd ed.). Oradell, NJ: Medical Economic Company, Inc. 
Attorney and Judicial Perceptions

Jacoubovitch, M. D., Bermant, G., Crockett, G. T. Mckinley, W. , \& Sanstad, A. (1977). Juror responses to direct and mediated presentations of expert testimony. Journal of. Applied Social Psychology, 7, 227-238.

Linz, D., Penrod, S., \& McDonald, E. (1986). Attorney communication and impression making in the courtroom: views from off the bench. Law and Human Behavior, 10, 281-302.

Litwack, T. R., Gerber, G. L. \& Fenster, C. A. (1979-80). The proper role of psychology in child custody disputes. Journal of Family Law, 18, 269-300.

Lowery, C. R. (1981). Child custody decisions in divorce proceedings: a survey of judges. Professional Psychology, 12 , 492-498.

Marafiote, R. A. (1985). The Custody of Children: A Behavioral Assessment Model. New York: Plenum Press. McCloskey, M., Egeth, H., McKenna, J. (1986). The experimental psychologist in court: the ethics of expert testimony. Law and Human Behavior, 10, 1-13.

McGinnies, E. \& Ward, C. D. (1980). Better liked than right: trustworthiness and expertise as factors in credibility. Personality and Social Psychology Bulletin, $6,467-472$.

Mnookin, R. H. (1975). Child-custody adjudication: judicial functions in the face of indeterminacy. Law and Contemporary Problems, 39, 226-288+.

Naftulin, D. H., Ware, J. E., Jr., \& Donnelly, F. A. (1973). The Doctor Fox lecture: a paradigm of educational seduction. Journal of Medical Education, 48, 630-635.

Nichols, J. F. (1982). The mental health professional as an expert witness. In P. A. Keller and L. G. Ritt (Eds.), Innovations in Clinical Practice: A Source Book (pp. 355362 ). Sarasota, FL: Professional Resource Exchange, Inc.

Okpaku, S. R. (1976). Psychology: impediment or aid in child custody cases? Rutgers Law Review, 29, 1117-1153.

Oster, A. M. (1965). Custody proceedings: a study of vague and indefinite standards. Journal of Family Law, 5, 2138 . 
Pipkin, W. E. Jr. (1989). Expert opinion testimony: experts, where did they come from and why are they here? Law and Psychology Review, 13, 101-118.

Saxe, D. B. (1975). Some reflections on the interface of law and psychiatry in child custody cases. Journal of Psychiatry and Law, 3, 501-514.

Schutz, B. M., Dixon, E. B., Lindenberger, J. C., \& Ruther, N. J. (1989). Solomon's Sword: A Practical Guide to Conducting Child Custody Evaluations. San Francisco: Jossey-Bass Inc.

Settle, S. A., \& Lowery, C. R. (1982). Child custody decisions: content analysis of a judicial survey. Journal of Divorce, 6(1/2), 125-38.

Sharf, B. F. (1986). Send in the clowns: the image of psychiatry during the Hinckley trial. Journal of Communication, 36(4), 80-93.

Skafte, D. (1985). Child Custody Evaluations: A Practical. Guide. Beverly Hills: Sage Publications.

Sorensen, E., \& Goldman, J. (1989). Judicial perceptions in determining primary physical residence. Journal of. Divorce, $12,69-87$.

Watson, A. S. (1978). On the preparation and use of psychiatric expert testimony: some suggestions in an ongoing controversy. Bulletin of the American Academy of Psychiatry and Law, 6, 226-246.

Weithorn, L. A., \& Grisso, T. (1987). Psychological evaluations in divorce custody: problems, principles, and procedures. In L. A. Weithorn (Ed.), Psychology and Child Custody Determinations: Knowledge, Roles, and Expertise (pp. ?-??). Lincoln, NE: University of Nebraska Press.

Woocher, F. D. (1986). Legal principles governing expert testimony by experimental psychologists. Law and Human Behavior, 10, 47-61.

Wyer, M. M., Gaylord, S. J., \& Grove, E. T. (1987). The legal context of child custody evaluations. In L. A.

Weithorn (Ed.), Psychology and Child Custody Determinations: Knowledge, Roles, and Expertise (pp. 3-22). Lincoln, NE: University of Nebraska Press. 
Attorney and Judicial Perceptions

Table 1

Correlations between the Scales on the SEWRF $\mathrm{TCFAF}_{\perp}$ and $\mathrm{KAF}$.

$$
\text { Expertise Trust Dynamism SEWRF KAF }
$$

Composite

\begin{tabular}{|c|c|c|c|c|c|}
\hline $\begin{array}{l}\text { TFA } \\
.101 \text { * }\end{array}$ & $-.121 \star$ & $-.120 \star$ & -.085 & $-.149 * *$ & - \\
\hline $\begin{array}{l}\text { TCA } \\
.137 \star *\end{array}$ & -.062 & -.105 & -.105 & $-.134 *$ & - \\
\hline $\mathrm{KAF}$ & .036 & .012 & -.026 & $.143 * *$ & 1.000 \\
\hline
\end{tabular}

* $\mathrm{p} \leq .05 \quad$ * $\mathrm{p} \leq .01$

Note. TFA=Traditional Family Attitudes, TCFAF Scale $\mathrm{TCA}=$ Traditional Court Attitudes, TCFAF Scale 
Attorney and Judicial Perceptions

Table 2

Unique Scale Contributions to the General and Specific_

Perceptions of Expert Witnesses (Semipartial Correlations).

$\begin{array}{lcl}\text { Traditional } & \text { Traditional } & \text { Knowledge } \\ \text { Court Attitudes } & \text { Family Attitudes } & \text { Assessment Form }\end{array}$

SEWRF

Composite $-.074 \quad-.102 \quad .120 *$ *

General -.180** $\quad-.022 \quad .053$

Measure

$\star \star \mathrm{p} \leq .01$ 
Attorney and Judicial Perceptions

Table 3

Regression Analyses of Demographic Variables on the SEWRF Composite and a General Measure of Perceived Expert Witness Helpfulness (Semipartial Correlations)

$\begin{array}{lll}\text { Years } & \text { Custody } & \text { Workshops } \\ \text { Since Receiving } & \text { Cases Involved in Attended } \\ \text { Law Degree } & & \end{array}$

SEWRF

Composite -.093 .259** .162*

General

Measure

$-.004$

$-.057$ $.146 * \star$

$\star \star \mathrm{p} \leq .01$ 
Attorney and Judicial Perceptions

Vitae 